\title{
LASER-ABLATION U-Th-Pb IN SITU DATING OF ZIRCON AND ALLANITE: AN EXAMPLE FROM THE OCTOBER HARBOUR GRANITE, CENTRAL COASTAL LABRADOR, CANADA
}

\author{
Richard A. COX ${ }^{\mathbb{I I}}$ AND DeReK H.C. WILTON ${ }^{\S}$ \\ Department of Earth Sciences, Memorial University of Newfoundland, St. John's, Newfoundland A1B 3X5, Canada
}

JAN KOŠLER

Department of Geochemistry, Charles University, Albertov 6, CZ-128 43 Prague 2, Czech Republic

\begin{abstract}
$\mathrm{U}-\mathrm{Th}-\mathrm{Pb}$ geochronology based on data acquired by laser-ablation microprobe - inductively coupled plasma - mass spectrometry (LAM-ICP-MS) has been applied to in situ dating of allanite and zircon in a single section of the October Harbour granite, Labrador. This is the first report of Th- $\mathrm{Pb}$ dating of allanite by the LAM-ICP-MS method, confirmed by zircon ages from the same section. Crystals as small as $20 \times 20 \mu \mathrm{m}$ have been analyzed in a standard polished section $100 \mu \mathrm{m}$ thick. Zircon crystals were examined using back-scattered electron images to identify features such as inherited cores, overgrowths and oscillatory growth. In this study, 45 LAM-ICP-MS analyses were carried out on 35 crystals of zircon. The U-Th- $\mathrm{Pb}$ zircon data suggest that the age of the granite is $1657 \pm 10 \mathrm{Ma}$ (MSWD $=0.77$, weighted mean ${ }^{207} \mathrm{~Pb} /{ }^{206} \mathrm{~Pb}$ ages from 25 concordant points). The data also indicate 1800-1850 Ma inheritance and patterns of multiple loss of lead in many grains. The allanite occurs as large euhedral crystals; they show elevated $\mathrm{U}$ and Th contents. Twenty-six analyses of two such crystals of allanite gave sixteen concordant points, obtained mainly from the low-Th core of a single large crystal, and a weighted mean ${ }^{208} \mathrm{~Pb} /{ }^{232} \mathrm{Th}$ age of 1635 $\pm 17 \mathrm{Ma}$ (MSWD = 2.1). Although complex Pb-loss is also recorded in portions of the allanite crystals analyzed, no evidence of inheritance was recorded. The age of the October Harbour granite is constrained to be $c a$. 1640-1660 Ma; it thus is significantly younger than the previously defined conventional multi-grain $\mathrm{U}-\mathrm{Pb}$ zircon age of $1719 \pm 3 \mathrm{Ma}$ attributed to the postulated parental intrusive complex, the Strawberry intrusive suite. The Strawberry suite thus may not be a single $c a$. 1720 Ma suite of rocks, but a more complex composite unit represented by rocks of widely differing ages.
\end{abstract}

Keywords: laser ablation, ICP-MS, U-Th-Pb geochronology, in situ dating, zircon, allanite, October Harbour granite, Labrador.

SOMMAIRE

Nous avons acquis des données géochronologiques (système $\mathrm{U}-\mathrm{Th}-\mathrm{Pb}$ ) par ablation au laser avec un plasma à couplage inductif et spectrométrie de masse (LAM-ICP-MS) afin de préciser in situ l'âge de l'allanite et du zircon dans une seule lame mince polie du granite de October Harbour, au Labrador. C'est la première fois que l'allanite est ainsi étudiée pour datation Th$\mathrm{Pb}$ par méthode LAM-ICP-MS, avec vérification des résultats par datation du zircon dans le même échantillon. Des cristaux atteignant à peine $20 \times 20 \mu \mathrm{m}$ ont même pu être analysés dans une lame mince polie d'une épaisseur de $100 \mu \mathrm{m}$. Au préalable, les cristaux de zircon ont été examinés avec des images d'électrons rétrodiffusés afin d'évaluer la présence de coeurs hérités, de surcroissances, et de croissance oscillatoire. Nous avons effectué 45 analyses LAM-ICP-MS de 35 cristaux de zircon. Selon les données U-Th- $\mathrm{Pb}$ obtenues sur zircon, l'âge du granite serait $1657 \pm 10 \mathrm{Ma}$ (MSWD $=0.77$, moyenne pondérée des âges ${ }^{207} \mathrm{~Pb} /$ ${ }^{206} \mathrm{~Pb}$ telle que déterminée avec 25 points concordants). Les données indiquent la présence de zircon hérité ayant un âge de 1800$1850 \mathrm{Ma}$, et des signes de pertes répétées de plomb dans plusieurs grains. L'allanite se présente en gros cristaux idiomorphes. Elle fait preuve de teneurs élevées en U et en Th. Vingt-six analyses de deux cristaux d'allanite ont donné seize points concordants, provenant surtout du noyau à faible teneur en Th d'un seul cristal, et une moyenne pondérée de l'âge ${ }^{208} \mathrm{~Pb} /{ }^{232} \mathrm{Th}$ de $1635 \pm 17 \mathrm{Ma}$ (MSWD $=2.1$ ). Quoique les signes d'une perte complexe de plomb sont aussi présents dans certaines portions de l'allanite, il n'y a aucun signe d'un coeur hérité. L'âge du granite de October Harbour serait d'environ 1640-1660 Ma, ce qui est passablement plus jeune que ce que l'on avait proposé antérieurement suite à une analyse conventionelle $\mathrm{U}-\mathrm{Pb}$ de plusieurs grains de zircon pris de la suite intrusive de Strawberry, soupçonnée d'être liée génétiquement, ce qui avait donné un âge de $1719 \pm 3$ Ma. La suite de

II Present address: School of Earth and Ocean Sciences, University of Victoria, P.O. Box 3055, Victoria, British Columbia V8W 3P6, Canada.

$\S \quad$ E-mail address: dwilton@esd.mun.ca 
Strawberry pourrait donc être plus complexe qu'une simple suite de roches mise en place il y a environ 1720 Ma, et contenir des roches d'âges très différents.

(Traduit par la Rédaction)

Mots-clés: ablation au laser, analyses ICP-MS, geochronologie U-Th-Pb, datation in situ, zircon, allanite, granite de October Harbour, Labrador.

\section{INTRODUCTION}

In this study, we present $\mathrm{U}-\mathrm{Th}-\mathrm{Pb}$ isotopic data derived by the in situ laser-ablation microprobe - inductively coupled plasma - mass spectrometry (LAMICP-MS) analyses of zircon and allanite from the October Harbour granite. This granite has been described as part of the Strawberry Intrusive suite, Makkovik Province, central coastal Labrador (Gower et al. 1982). We selected it for this study because of (1) its undeformed nature, (2) its regional geological significance as a member of a previously dated intrusive suite, and (3) the presence of large crystals of an allanitegroup mineral, presumably allanite-(Ce) ( $c f$. Wilton 1996), along with concentrations of euhedral, large crystals of zircon; this latter fact was important, as the zircon could be used as a means of confirming isotopic dates derived from the allanite. Ours is the first attempt at dating allanite with the LAM-ICP-MS technique; we provide an illustration of the in situ capabilities of the LAM-ICP-MS U-Th-Pb technique for age determinations in the granite. In addition, we observed a record of complex Pb-loss and inheritance using a total of 45 analyses of zircon and 26 of allanite, all carried out on a single $4.5 \times 2.5 \mathrm{~cm}$ polished section $100 \mu \mathrm{m}$ thick.

\section{BACKGROUND INFORMATION}

$\mathrm{U}-\mathrm{Pb}$ dating of accessory minerals has become the cornerstone technique for resolving the ages of rocks, to ultimately constrain the timing and rates of geological processes. By far the most commonly dated mineral is zircon $\left(\mathrm{ZrSiO}_{4}\right)$. Zircon has relatively elevated $\mathrm{U}$ contents (5-4000 ppm) and excludes common $\mathrm{Pb}$ from its structure, thus making it ideal for $\mathrm{U}-\mathrm{Pb}$ dating. Zircon also occurs in almost the complete spectrum of intrusive igneous rock-types; within intrusive rocks, the morphology of zircon is generally highly distinctive (e.g., Pupin 1980, Vavra 1993). Zircon is also recognized as one of the few primary igneous phases that can survive the highest grades of metamorphism, up to partial melting, yet can also occur as a growth product in high-grade metamorphic rocks. Conversely, allanite presents considerable problems for isotopic dating, for example a range of possible compositions with variable contents of common $\mathrm{Pb}$ as well as the potential for metamictization-induced loss of elements.

Complex growth-histories can be revealed through the documentation of internal zoning within single crys- tals of zircon (e.g., Hanchar \& Miller 1993, Vavra et al. 1996, Hoskin \& Black 2000). Owing to its resistance to chemical change and physical processes, zircon is also common as detritus in sedimentary rocks, which in turn can be recycled through several geological events. The robust nature of zircon has led to the general conclusion that zircon will survive in the crustal environment almost indefinitely (Mezger \& Krögstad 1997).

As a direct result of the potential complications due to its robust nature, zircon dating utilizing $\mathrm{U}-\mathrm{Pb}$ extraction from the sample by dissolution and cation-exchange chemistry, followed by analysis via thermal-ionization mass spectrometry (TIMS), has progressively focused on smaller sizes of samples. To elucidate potential problems, some investigators have imaged the internal structure of single grains prior to analysis (e.g., Corfu et al. 1994, Poller et al. 1997, Connelly 2000). Alternatively, in situ analysis has been undertaken using one of two high-resolution secondary-ionization mass spectrometers (SIMS), namely the SHRIMP (e.g., Williams 1998, Compston 1999) and the Cameca IMS 1270 (e.g., Whitehouse et al. 1997, Harrison et al. 1999). Although the mean precision of ion-probe instruments $(0.5-4 \%$, $2 \sigma$ ) is around $5-10 \times$ lower than for conventional singlegrain TIMS dating (Williams 1998), the spatial resolution is such that domains as small as $15-35 \mu \mathrm{m}$ in diameter can be analyzed. An important limitation to these techniques, however, is that ionization of complex matrices has led to the restriction of the methods largely to zircon dating; dates based on monazite-(Ce), (Ce,La,Th) $\mathrm{PO}_{4}$, and xenotime-(Y), $\mathrm{YPO}_{4}$, have recently been documented (e.g., Grove \& Harrison 1999, McNaughton et al. 1999, Stern \& Berman 2000). The dating of other phases has only rarely been attempted (e.g., titanite: Kinny \& Friend 1997; allanite: Catlos et al. 2000).

A rapidly developing technique for $\mathrm{U}-\mathrm{Th}-\mathrm{Pb}$ isotope micro-analysis and mineral dating, the LAM-ICPMS method, has evolved from initial experiments where ${ }^{207} \mathrm{~Pb} /{ }^{206} \mathrm{~Pb}$ ages were calculated on single crystals (e.g., Feng et al. 1993, Fryer et al. 1993) to fully quantitative $\mathrm{U}-\mathrm{Th}-\mathrm{Pb}$ dating of accessory phases with both singlecollector (Horn et al. 2000, Knudsen et al. 2001, Košler et al. 2002) and multi-collector (Machado \& Simonetti 2001, White et al. 2001) ICP-MS platforms. The LAMICP-MS technique of U-Th-Pb dating offers many of the same advantages as SIMS instruments, namely high spatial resolution and high throughput of samples. 


\section{Geological Setting}

The Makkovik Province is a relatively small Paleoproterozoic terrane situated between the Nain and Grenville provinces of central Labrador (Fig. 1a); it is the western extension of the much larger Ketilidian mobile belt of southern Greenland (Kerr et al. 1996). The terrane has been divided into three lithotectonic zones, namely the Kaipokok, Aillik and Cape Harrison domains, which have been the focus of several $\mathrm{U}-\mathrm{Pb}$ geochronology studies. Two main packages of intrusive and related volcanic rocks can be recognized and grouped in the ranges 1910-1880 and 1850-1780 Ma (Schärer et al. 1988, Kerr et al. 1992, Ketchum et al. 1997, 2001a). Metamorphism during the Makkovikian orogeny seems to have occurred in two pulses: (1) a pre1800 Ma event recorded by monazite, titanite and syntectonic intrusions, and (2) a $c a$. 1790-1750 Ma event recorded by titanite ages from various rocks that may represent later thermal events associated with shearing. The third major suite of intrusions and associated supracrustal rocks dated at $c a$. $1650 \mathrm{Ma}$ is thought to represent Labradorian orogenic activity (Schärer $e t$ al. 1988, Kerr et al. 1992).

A less abundant suite of accessory-mineral-rich, post-tectonic intrusions have also been dated at $\mathrm{ca}$. 1710-1720 Ma (Kerr et al. 1992, Ketchum et al. 1997). These rocks are somewhat enigmatic in that they are significantly younger than intrusions associated with the Makkovikian orogeny, and yet they are older than Labradorian intrusive suites. Intrusions in the 19001800 and $1650 \mathrm{Ma}$ age ranges are common in southern Labrador, whereas intrusions in the 1700-1750 Ma range are rare. In the Makkovik region, the $1719 \mathrm{Ma}$ Strawberry Intrusive suite is metallogenically very similar to $c a$. $1650 \mathrm{Ma}$ suites, as both have associated stockwork-like occurrences of polymetallic minerals, e.g., molybdenite - uraninite - galena - sphalerite fluorite (Wilton 1996). On the basis of the ages and geochemical data, it has been suggested that the intrusions of intermediate age (i.e., 1710-1720 Ma), along with the rest of the Cape Strawberry Intrusive suite, represent an A-type granitic suite emplaced very late in the history of the Makkovikian orogeny (Kerr \& Fryer 1994, Barr et al. 2001). We have chosen a previously undated phase of the Cape Strawberry Intrusive suite, the October Harbour granite, to carry out a detailed investigation of the U-Th-Pb systematics of zircon and allanite using in situ LAM-ICP-MS techniques.

\section{LAM-ICP-MS ANALYSIS}

\section{General method}

In situ LAM-ICP-MS analyses of areas within the selected crystals of zircon and allanite were carried out using a VG PlasmaQuad PQ-2S+ instrument coupled to an in-house-built $266 \mathrm{~nm}$ NdYAG laser at Memorial
University of Newfoundland (Jackson et al. 1992). The sample-introduction system has been modified to enable nebulization of a tracer solution at the same time as laser ablation of the solid sample. The methods broadly follow those of Košler et al. (2002), but with a somewhat different tracer solution. In this study we used a mixed tracer solution of ${ }^{203} \mathrm{Tl}-{ }^{205} \mathrm{Tl}-{ }^{209} \mathrm{Bi}-{ }^{233} \mathrm{U}-{ }^{237} \mathrm{~Np}$ with $c a .10 \mathrm{ppb}$ of each element. The tracer solution was aspirated into the plasma along with an argon-helium carrier-gas mixture through a Glass Expansion microconcentric nebulizer, Scott-type double-pass spray chamber and a T-piece tube attached to the back end of the plasma torch. The instrument sensitivity in solution mode was $c a$. $60,000 \mathrm{cps} / \mathrm{ppb}$ of a mono-isotopic element, e.g., ${ }^{209} \mathrm{Bi}$. A helium gas line carrying the sample from the laser cell $\left(50 \mathrm{~cm}^{3}\right)$ to the plasma was attached to the T-piece tube. The sample cell held up to four round grain-mounts $7 \mathrm{~mm}$ across containing reference standards and a single $4.5 \times 2.5 \mathrm{~cm}$ polished thin section of a rock sample.

The laser was set up to produce a spot $5-20 \mu \mathrm{m}$ in diameter, with an energy of $0.2-0.5 \mathrm{~mJ} /$ pulse for zircon and $0.15-0.25 \mathrm{~mJ} / \mathrm{pulse}$ for allanite (measured before the laser beam entered the objective of the microscope), using a repetition rate of $10 \mathrm{~Hz}$. The laser beam was focused $100-200 \mu \mathrm{m}$ above the surface of the sample surface. The cell was mounted on a motorized stage, which, during the ablation, was moved beneath the stationary laser beam to produce various raster pits in the analyzed minerals. Different shapes of the raster pits were used to keep the beam within areas of interest while providing a large-enough area to minimize the depth of the ablation. The rate at which the laser penetrates the surface of a sample varies with the total power used, beam size and area of the raster. Using a 30 $\times 30 \mu \mathrm{m}$ raster and a $10 \mu \mathrm{m}$ beam, the laser completed a square slice every 9 seconds. With a power of $0.5 \mathrm{~mJ} /$ pulse, the depth of each slice was typically about 0.3 $\mu \mathrm{m}$. In total, 200 seconds of laser time was used for all samples, and thus the depth of the $30 \times 30 \mu \mathrm{m}$ raster using $0.5 \mathrm{~mJ} / \mathrm{pulse}$ would be about $6 \mu \mathrm{m}$. Previous studies have demonstrated that both laser-beam defocus (Jackson et al. 1996, Jackson 2001) and rastering (Parrish et al. 1999) result in a more efficient removal of material from the ablation site and substantially reduce elemental fractionation among $\mathrm{U}$, Th and $\mathrm{Pb}$ (Li et al. 2001, White et al. 2001).

Back-scattered electron (BSE) images typically record the structure of a sample to about $8 \mu \mathrm{m}$ depth (Reed 1995). We are thus relatively confident that we have analyzed the same part of the zircon that was previously imaged. Typical acquisitions consisted of a $40 \mathrm{~s}$ measurement of gas blank and aspirated solution just before the start of ablation. During ablation, $\mathrm{Pb}$, Th and $\mathrm{U}$ signals from the sample, along with the continuous signals from the aspirated solution, were acquired for 200 seconds. The data were acquired in time-resolved peak-jumping, pulse-counting mode with one point 


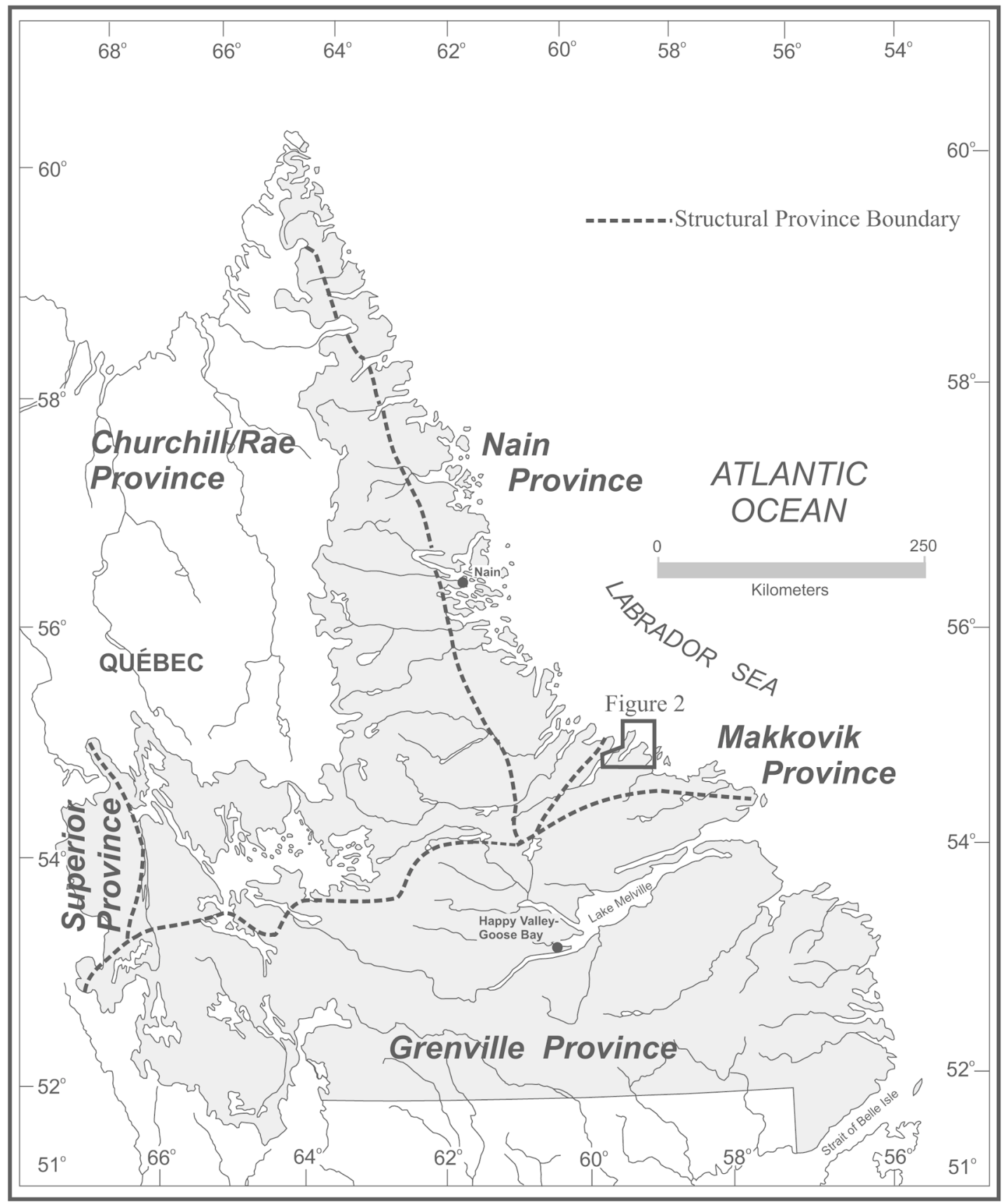

FIG. 1a. Map showing the general location of the Makkovik Province in central coastal Labrador.

measured per peak for masses 202 (Hg, flyback), 203 (Tl), $205(\mathrm{Tl}), 206(\mathrm{~Pb}), 207(\mathrm{~Pb}), 208(\mathrm{~Pb}), 209(\mathrm{Bi})$, 232 (Th), $233(\mathrm{U}), 237(\mathrm{~Np}), 238(\mathrm{U}), 248\left({ }^{232} \mathrm{Th}^{16} \mathrm{O}\right)$, $249\left({ }^{233} \mathrm{U}^{16} \mathrm{O}\right), 253\left({ }^{237} \mathrm{~Np}{ }^{16} \mathrm{O}\right)$ and $254\left({ }^{238} \mathrm{U}^{16} \mathrm{O}\right)$. Qua- drupole settling-time was $1 \mathrm{~ms}$, and the dwell time was $8.3 \mathrm{~ms}$ on each mass except for ${ }^{208} \mathrm{~Pb}(16.6 \mathrm{~ms})$ and ${ }^{207} \mathrm{~Pb}$ (24.9 ms). Over 200 seconds of measurement, about 1200 data-acquisition cycles (sweeps) were collected. 


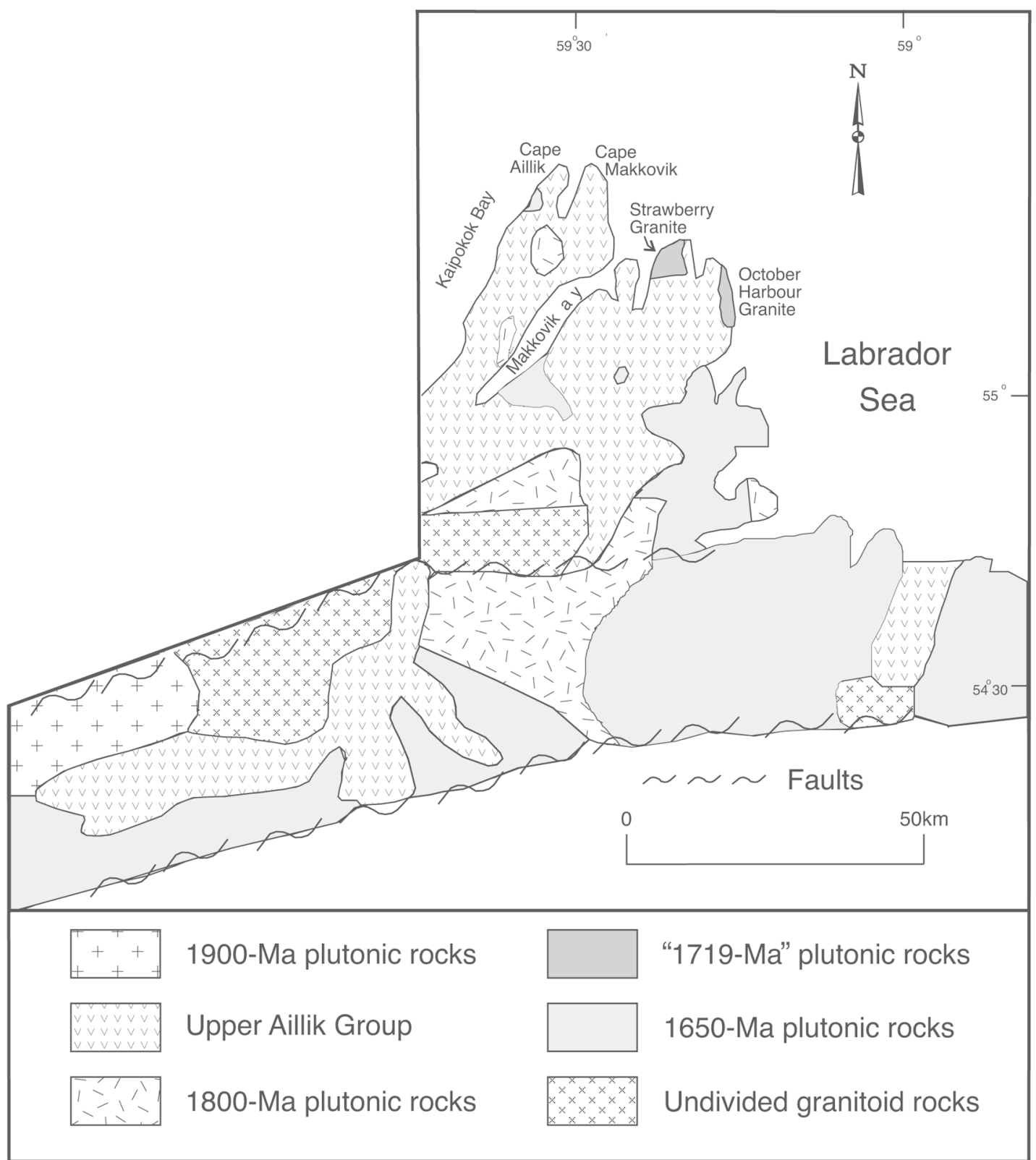

FIG. 1b. Map showing the main lithological units in the southern Makkovik Bay and the location of the October Harbour Granite (adapted from Wilton 1996).

\section{Data reduction}

Raw data were corrected for electron-multiplier dead time (20 ns) and processed off-line using an EXCEL spreadsheet program (LAMDATE) to integrate signals from each sequential set of 10 sweeps; the method follows that of Košler et al. (2002). The measured U/Pb and $\mathrm{Th} / \mathrm{Pb}$ values during the ablation show a linear increase with the number of laser pulses applied. This fractionation can be corrected for using a least-squares linear 
regression of the measured values of the isotopic ratios and calculation of the values of those ratios at zero ablation time. The regression follows the form:

$$
\mathrm{R}=\mathrm{R}_{\mathrm{o}}+\mathrm{ST}
$$

where $R$ is the measured value of the isotopic ratio, $R_{0}$ is the value at the start of the ablation (raster), $\mathrm{S}$ is the slope of the line, and $\mathrm{T}$ is the laser-ablation time slice. The fractionation-corrected value is calculated as:

$$
\mathrm{R}_{\mathrm{o}}=\left(\Sigma \mathrm{r}_{\mathrm{i}} \mathrm{St}^{2}{ }_{\mathrm{i}}-\Sigma \mathrm{t}_{\mathrm{i}} \mathrm{St}_{\mathrm{i}} \mathrm{r}_{\mathrm{i}}\right) /\left(\mathrm{n} \Sigma \mathrm{t}^{2}{ }_{\mathrm{i}}-\left(\Sigma \mathrm{t}_{\mathrm{i}}\right)^{2}\right)
$$

where $\mathrm{n}$ is the number of number of integrated sweeps, $t_{i}$ and $r_{i}$ are individual time and isotopic values summed over the acquisition. The error of the intercept controls the error of the corrected isotopic values and is calculated as:

$$
\begin{aligned}
& \sigma_{R(0)}=\sqrt{ }\left[(1 / n)+\left(t^{2}{ }_{M} / \Sigma\left(t_{i}-t_{m}\right)^{2}\right)\right] * \\
& \sqrt{ }\left[\Sigma\left(r_{i}-r_{i}\right)^{2} /(n-2)\right]
\end{aligned}
$$

where $t_{M}$ is the mean acquisition-time, and $\mathrm{rr}_{\mathrm{i}}$ is the value of the isotopic ratio calculated from the linear regression as $\mathrm{R}_{\mathrm{o}}+\mathrm{St}_{\mathrm{i}}$.

The isotopic ratios were then corrected for gas and tracer solution blank and minor formation of oxide before the correction for instrument mass-bias. The massbias correction utilized the power law and the ratio measurements of the isotopic tracer solution (Horn et al. 2000, Košler et al. 2002). The uncertainty of this value was also propagated through the calculation of isotopic values. It has been demonstrated that accuracy and precision of isotopic measurements by ICP-MS can be improved if the mean mass of the elements in the normalizing ratio that is used is identical or close to the mean mass of the elements in the ratio to be normalized (Hirata 1996, Vance \& Thirwall 2002). In addition, where isotopes of two elements are used to correct for mass bias of a third element (e.g., where the ${ }^{209} \mathrm{Bi} /{ }^{205} \mathrm{Tl}$ value is used to correct for the mass bias of the ${ }^{207} \mathrm{~Pb} /$ ${ }^{206} \mathrm{~Pb}$ value), the tracer isotopes should also have ionization potentials and rates of oxide formation in the ICP that are similar to the isotopes of interest in the sample. To improve the efficiency of the mass-bias correction of laser-ablation data for $\mathrm{U}-\mathrm{Th}-\mathrm{Pb}$ dating, we have used the following scheme of corrections (see also Košler \& Sylvester 2003): the ${ }^{209} \mathrm{Bi} /{ }^{205} \mathrm{Tl}$ value (mean nominal mass 207) was used to "mass-bias-correct" the ${ }^{207} \mathrm{~Pb} /$ ${ }^{206} \mathrm{~Pb}$ value (mean nominal mass 206.5 ), the ${ }^{205} \mathrm{Tl} /{ }^{237} \mathrm{~Np}$ value (mean mass 221) was used to correct the ${ }^{207} \mathrm{~Pb} /$ ${ }^{235} \mathrm{U}$ value (mean mass 221 ), the ${ }^{205} \mathrm{Tl} /{ }^{237} \mathrm{~Np}$ value (mean mass 221) was used to correct the ${ }^{206} \mathrm{~Pb} /{ }^{238} \mathrm{U}$ value (mean mass 222 ), the ${ }^{209} \mathrm{Bi} /{ }^{233} \mathrm{U}$ value (mean mass 221) was used for correction of the ${ }^{208} \mathrm{~Pb} /{ }^{232} \mathrm{Th}$ value (mean mass 220 ), and the ${ }^{233} \mathrm{U} /{ }^{237} \mathrm{~Np}$ value (mean mass 235) was used to correct the ${ }^{232} \mathrm{Th} /{ }^{238} \mathrm{U}$ value (mean mass 235). The efficiency of the mass-bias correction as well as the correction for laser-induced fractionation were monitored by replicate measurements of the 91500 zircon reference material (Weidenbeck et al. 1995) and an in-house zircon standard 02123 (Ketchum et al. 2001b) that were performed before and after every six analyses of unknown samples of zircon. The average $U$ concentrations for each analysis were determined by direct comparison using 91500, which has a mean $U$ concentration value of $81.2 \mathrm{ppm}$ (Weidenbeck et al. 1995). The errors using the external calibration method are about $10 \%$ for the unknown values.

Correcting the $\mathrm{Pb}$-isotope signals from the zircon for initial common $\mathrm{Pb}$ is problematic. Firstly, the amount of common $\mathrm{Pb}$ in zircon is extremely small. In the 91500 standard, for example, the ${ }^{206} \mathrm{~Pb} /{ }^{204} \mathrm{~Pb}$ values vary from 12,000 to 161,800 , equivalent to less than $0.15 \%$ of common $\mathrm{Pb}$. Secondly, ${ }^{204} \mathrm{Hg}$ in the argon gas causes an isobaric interference on ${ }^{204} \mathrm{~Pb}$, making accurate measurement of ${ }^{204} \mathrm{~Pb}$ concentration in zircon difficult. To measure and correct for common $\mathrm{Pb}$ present in zircon, we used the ${ }^{208} \mathrm{~Pb} /{ }^{206} \mathrm{~Pb}-{ }^{232} \mathrm{Th} /{ }^{238} \mathrm{U}$ method (Compston et al. 1984), which is quite commonly applied to zircon data collected using the SHRIMP (Williams 1998, and references therein).

The LAM-ICP-MS procedure for allanite was essentially identical, except that a large single crystal of allanite from the Atesina Volcanic Complex (referred to from this point as AVC-1) was used as a standard. Allanite from this sample has been dated using both U$\mathrm{Pb}$ and $\mathrm{Th}-\mathrm{Pb}$ ID-TIMS (Barth et al. 1994) and Th- $\mathrm{Pb}$ ion-probe techniques (Catlos et al. 2000). The overall variation in the ${ }^{238} \mathrm{U}$ signal from AVC-1 over the course of this study was less than $2 \%$; the measured variation in $\mathrm{U}$ content is quite large, however, with values between 79.6 and 152.9 ppm (Barth et al. 1994). Thus, we have assigned an error in values of $U$ concentration for the allanite in the October Harbour sample of $25 \%$ to account for potential variation in the AVC-1 standard. Allanite can contain appreciable quantities of common $\mathrm{Pb}$ (Heaman \& Parrish 1991), and a correction for initial common $\mathrm{Pb}$ is required. Owing to ${ }^{204} \mathrm{Hg}$ interference, the ${ }^{204} \mathrm{~Pb}$ signal could not be accurately measured. In addition, the high content of Th in allanite renders the ${ }^{208} \mathrm{~Pb} /$ ${ }^{206} \mathrm{~Pb}-{ }^{232} \mathrm{Th} /{ }^{238} \mathrm{U}$ method unsuitable. For this study, we tested the ${ }^{207} \mathrm{~Pb} /{ }^{206} \mathrm{~Pb}$ method (Williams 1998) to correct for common $\mathrm{Pb}$ in allanite. This method involves taking an assumed age for the sample and calculating the proportion of common $\mathrm{Pb}$ based on any excess in the measured ${ }^{207} \mathrm{~Pb} /{ }^{206} \mathrm{~Pb}$ value. In general, this method is used for Phanerozoic rocks where the range of ${ }^{207} \mathrm{~Pb} /{ }^{206} \mathrm{~Pb}$ values is small (e.g., Ireland \& Gibson 1998). For allanite, however, the Th-Pb system has been shown to be less easily disturbed than the U-Pb system (Barth et al. 1994), and both the ${ }^{206} \mathrm{~Pb} /{ }^{238} \mathrm{U}$ and ${ }^{208} \mathrm{~Pb} /{ }^{232} \mathrm{Th}$ ages are relatively insensitive to common $\mathrm{Pb}$. The corrected ${ }^{206} \mathrm{~Pb} /$ ${ }^{238} \mathrm{U}$ and ${ }^{208} \mathrm{~Pb} /{ }^{232} \mathrm{Th}$ values can be used to examine concordance, a typical method for other high-Th minerals such as monazite (Foster et al. 1999, White et al. 2001). 


\section{Results from 91500 and AVC-1 standards}

$\mathrm{U}-\mathrm{Th}-\mathrm{Pb}$ values for zircon and allanite were corrected for common $\mathrm{Pb}$ using the Stacey \& Kramers (1975) model for $\mathrm{Pb}$ evolution. Ages were calculated using the decay constants of Steiger \& Jäger (1977). Corrected $\mathrm{LAM}{ }^{206} \mathrm{~Pb} /{ }^{238} \mathrm{U}$ and ${ }^{207} \mathrm{~Pb} /{ }^{206} \mathrm{~Pb}$ values for the 91500 zircon standard ( $\mathrm{N}=14$ measurements), taken over the course of this study, were $0.1801 \pm 0.0034$ and $0.0747 \pm 0.0080$ which correspond to ages of $1067 \pm 18$ and $1060 \pm 22 \mathrm{Ma}$, respectively (values expressed at the
95\% confidence interval). The data are shown in Figure 2a. These values are in close agreement with the accepted ${ }^{206} \mathrm{~Pb} /{ }^{238} \mathrm{U}$ value of $0.17917 \pm 0.00008$, corresponding to an age of $1062.4 \pm 0.4 \mathrm{Ma}$, and the ${ }^{207} \mathrm{~Pb} /$ ${ }^{206} \mathrm{~Pb}$ value of $0.07488 \pm 0.00001$, corresponding to an age of $1065 \pm 0.3 \mathrm{Ma}$ (Weidenbeck et al. 1995). For AVC -1 , the corrected LAM data $(\mathrm{N}=11)$ yielded a weighted mean ${ }^{208} \mathrm{~Pb} /{ }^{232} \mathrm{Th}$ value of $0.01376 \pm 0.0004$ and $\mathrm{a}^{206 \mathrm{~Pb} / 238} \mathrm{U}$ value of $0.0435 \pm 0.0014$, which correspond to ages of $276 \pm 7.9$ and $274.5 \pm 8.6 \mathrm{Ma}$ (values expressed at the $95 \%$ confidence interval) and shown in

a)

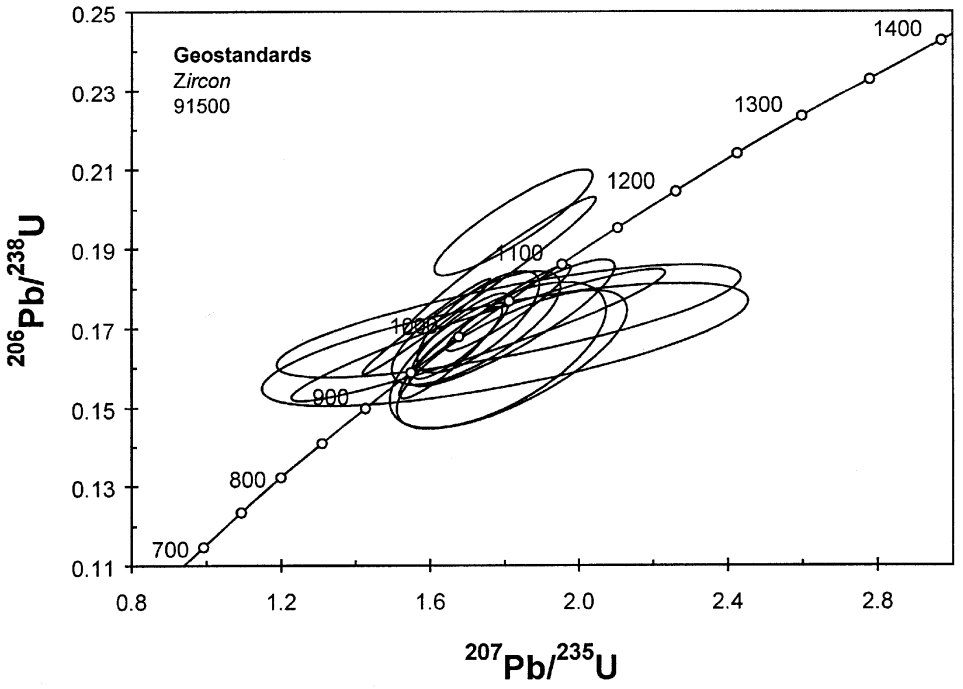

b)

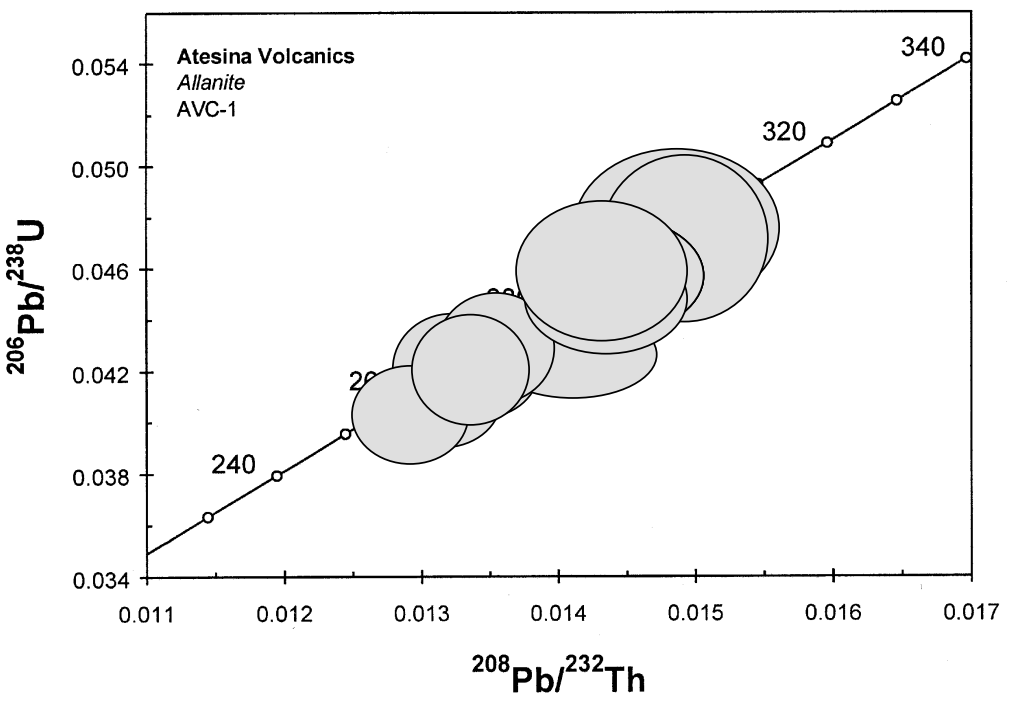

FIG. 2. Concordia plots for (a) 91500 (zircon) and (b) AVC-1 (allanite) reference materials. 
Figure $2 \mathrm{~b}$. These values closely match the ID-TIMS values of $0.01376 \pm 0.00008$ and $0.044235 \pm 0.00012$, corresponding to ages of $276.25 \pm 3.1$ and $279 \pm 0.75$ $\mathrm{Ma}$ for ${ }^{208} \mathrm{~Pb} /{ }^{232} \mathrm{Th}$ and ${ }^{206} \mathrm{~Pb} /{ }^{238} \mathrm{U}$, respectively (Barth et al. 1994). The final ages for the standards and the October Harbor granite were produced using the Isoplot/ Ex macro (Ludwig 1999) in conjunction with the LAMDATE EXCEL spreadsheet program (Košler et al. 2002).

\section{SAMPLe Descriptions}

\section{Sample location and general description}

The October Harbour granite crops out as a small $(2.5 \times 1 \mathrm{~km})$ body south of Pomiadluk Point (Fig. 1b). The intrusion cuts Upper Aillik Group rocks and, near the contact, contains abundant xenoliths of felsic volcanic rocks and amphibolite of this $c a$. 1860 Ma group. Gower et al. (1982) linked the October Harbor granite with the nearby Strawberry granite, which crops out 4 $\mathrm{km}$ to the northwest, on the basis of similar primary and secondary mineralogy. The October Harbor granite essentially consists of equal quantities of equigranular $\mathrm{K}$ feldspar (orthoclase and lesser microcline), plagioclase (oligoclase) and quartz, with mafic clusters of biotite, hornblende and lesser oxide minerals. The mafic components comprise about $10-20 \%$ of the whole rock. In addition, large, subhedral crystals of allanite, up to $1.5 \mathrm{~mm}$ in length, are evenly distributed throughout the rock. Allanite is located within both felsic and mafic minerals, suggesting that it is part of the main assemblage of the granite, growing throughout the crystallization history.

The analyzed whole-rock sample was cut into thin slices using a conventional rock saw, and appropriate areas were chosen for sectioning. The trimmed chips were mounted on plain $4.5 \times 2.5 \mathrm{~cm}$ glass slide mounts and polished down to $100 \mu \mathrm{m}$ in thickness, allowing for examination of translucent phases such as K-feldspar, quartz and plagioclase in transmitted light. Minerals such as hornblende and biotite, however, are almost opaque, making the identification of accessory minerals included in these phases difficult. A scanning electron microscope (SEM) was used in back-scattered electron (BSE) mode to locate zircon crystals and image any internal structures that might be present (Fig. 3). Allanite was also carefully examined using both BSE images (Fig. 4) and reflected light microscopy. The carbon coating was then carefully removed, after which the zircon and allanite grains were located in the section using reflected light prior to LAM-ICP-MS analysis. After LAM-ICP-MS analysis, the shapes and depths of the analyzed areas were examined using secondary electron images. Although we originally examined six polished sections of the granite, we found that we had sufficient data from the LAM-ICP-MS analysis of one section to complete the study.

\section{Zircon morphology and internal structures}

The zircon crystals in the October Harbour granite can be divided into two basic morphological types. Crystals are either elongate along the $Z$ axis with approximate $z-x$ dimensions ranging from $5: 1$ to $3: 1$, or they are prismatic, ranging in shape from almost square in cross section to diamond-shaped, euhedral crystals. In addition, the elongate crystals display a range in the number of faces present. On the basis of the classification scheme of Pupin (1980), the morphological types in the October Harbour granite most likely represent a crystallization sequence from high temperatures evolving through elongate and simple prism morphology to more highly faceted crystals.

Various internal structures are revealed in SEMBSE images (Fig. 3); several crystals show signs of a resorbed core, with damage caused by a high $U$ content. For example, crystals labeled 1-4 and 1-9 are prismatic with a complexly zoned core, surrounded by a relatively unzoned overgrowth. The overgrowths have a series of radiating fractures extending from the core to the grain boundary. This structure most likely represents a high$\mathrm{U}$ core, which has caused damage to the overgrowth due to $\alpha$-particle emission. Similarly, the grains labeled 1-2 and 1-11 display an obvious core, with evidence of resorption. Grain 1-2 displays a smaller, bright (high-U) core surrounded by a wide oscillatory-zoned prismatic structure, whereas grain 1-11 shows a very complex pattern of zonation in the core, which occupies much of the crystal, and a narrow bright overgrowth. In contrast, the crystal labeled 1-1 (prismatic) and 1-3 (elongate) display almost continuous oscillatory zoning from core to rim, suggesting only one phase of growth. An interesting point to note is that the only internal structure visible in either reflected or incident light are the cores and damaged overgrowths, as in the grain 1-4 example. Although this may in part reflect the in situ examination of these crystals, it remains a strong possibility that picking zircon fractions from this sample under incident light alone would result in mixed populations. The crystals shown in Figure 3 were analyzed, by LAM-ICPMS with the raster pattern indicated, along with the analysis number listed against the $\mathrm{U}-\mathrm{Th}-\mathrm{Pb}$ data in Table 1. The areas were selected on the basis of an assumption that complex cores with damaged overgrowths and crystals with cores and oscillatory or undamaged overgrowths represent xenocrysts (inherited cores) with magmatic overgrowths, and that continuous oscillatory zoning represents a single phase of zircon most likely grown entirely from the granitic magma.

\section{Characteristics of the allanite crystals}

Allanite is a common accessory phase in many granitic rocks, particularly where the magma is more Caand Al-rich (Broska \& Siman 1998). The mineral has considerable potential for geochronology; in particular, 
TABLE 1. LAM-ICP-MS DATA ON ZIRCON, OCTOBER HARBOUR GRANITE, CENTRAL COASTAL LABRADOR

\begin{tabular}{|c|c|c|c|c|c|c|c|c|c|c|c|c|c|c|c|c|c|}
\hline \multirow[b]{2}{*}{$\begin{array}{l}\text { Spot } \\
\#\end{array}$} & \multirow[b]{2}{*}{$\begin{array}{l}\text { Analysis pattern } \\
\text { and description }\end{array}$} & \multirow[b]{2}{*}{$\begin{array}{l}{ }^{3} \mathrm{U} \\
\mathrm{ppm}\end{array}$} & \multirow[b]{2}{*}{${ }^{232} \mathrm{Th}$} & \multirow[b]{2}{*}{${ }^{200} \frac{\mathrm{Pb}}{\mathrm{Pb}}$} & \multirow[b]{2}{*}{$\begin{array}{c}{ }^{4} \mathrm{f} 206 \\
\%\end{array}$} & \multicolumn{6}{|c|}{ Calculated values (corrected for common $\mathrm{Pb}$ ) } & \multicolumn{6}{|c|}{ Apparent ages (Ma) } \\
\hline & & & & & & ${ }_{23}^{207} \mathrm{~Pb}$ & \pm & ${ }^{2306} \mathrm{~Pb}$ & \pm & ${ }^{206} \mathrm{~Pb}$ & \pm & ${ }^{235} \mathrm{~Pb}$ & \pm & ${ }^{206} \mathrm{~Pb}$ & \pm & ${ }^{206} \mathrm{~Pb}$ & $\begin{array}{r} \pm \% \\
\text { conc }\end{array}$ \\
\hline $1-1 \mathrm{a}$ & $\mathrm{S}, \mathrm{p}$, int/core & 114 & 4502 & 0.1298 & 0.74 & 3.9671 & 0.0577 & 0.2862 & 0.0043 & 0.1005 & 0.0014 & 1627 & 12 & 1623 & 21 & 1634 & $14 \quad 99$ \\
\hline $1-1 b$ & S, tip & 94 & 0.3381 & 0.0975 & 0.77 & 4.0715 & 0.0728 & 0.2886 & 0.0041 & 0.1023 & 0.0018 & 1649 & 15 & 1635 & 20 & 1667 & $17 \quad 98$ \\
\hline $1-2 a$ & $\mathrm{~S}, \mathrm{p}$, core, & 349 & 0.2550 & 0.0729 & 0.24 & 3.8293 & 0.0652 & 0.2733 & 0.0040 & 0.1016 & 0.0010 & 1599 & 14 & 1557 & 20 & 1654 & $10 \quad 94$ \\
\hline $1-2 b$ & LR, edge (oscil.) & 62 & 0.3915 & 0.1129 & 2.12 & 4.2519 & 0.1268 & 0.3035 & 0.0064 & 0.1016 & 0.0035 & 1684 & 25 & 1708 & 31 & 1654 & 32103 \\
\hline $1-3$ & LR, elong, core & 153 & 0.1722 & 0.0496 & 2.07 & 2.3276 & 0.1014 & 0.1329 & 0.0047 & 0.1270 & 0.0061 & 1221 & 31 & 804 & 27 & 2057 & $43 \quad 39$ \\
\hline $1-4$ & $\mathrm{~S}, \mathrm{p}$, core & 4721 & 0.4202 & 0.1212 & 1.70 & 0.6616 & 0.0111 & 0.0729 & 0.0011 & 0.0658 & 0.0006 & 516 & 7 & 454 & 7 & 801 & $10 \quad 57$ \\
\hline $1-5$ & $\mathrm{~S}(20 \times 20), \mathrm{p}$, int $/ \mathrm{rim}$ & 173 & 0.2195 & 0.0640 & 0.31 & 4.1177 & 0.0600 & 0.2797 & 0.0046 & 0.1068 & 0.0015 & 1658 & 12 & 1590 & 23 & 1745 & 1391 \\
\hline $1-6 a$ & 20), elong, int & 145 & 0.2380 & 0.0694 & 1.11 & 0.4928 & 0.0286 & 0.0590 & 0.0020 & 0.0606 & 0.0029 & 407 & 19 & 369 & 12 & 625 & $56 \quad 59$ \\
\hline $1-6 b$ & $\mathrm{~S}(2$ & 195 & 0.2477 & 0.0722 & 0.73 & 4.0792 & 0.0629 & 0.2790 & 0.0047 & 0.1060 & 0.0014 & 1650 & 13 & 1586 & 24 & 1732 & 1392 \\
\hline $1-7$ & LR, elong, & 409 & 0.1537 & 0.0448 & 1.80 & 2.4961 & 0.0888 & 0.1872 & 0.0061 & 0.0967 & 0.0020 & 1271 & 26 & 1106 & 33 & 1562 & 2071 \\
\hline $1-8 \mathrm{a}$ & $\mathrm{S}, \mathrm{p}, \mathrm{rim}$ & 216 & 0.2551 & 0.0738 & 0.71 & 4.5203 & 0.0385 & 0.2977 & 0.0022 & 0.1101 & 0.0010 & 1735 & 7 & 1680 & 11 & 1802 & 893 \\
\hline $1-8 b$ & LR, edge & 192 & 0.2639 & 0.0763 & 1.22 & 4.4851 & 0.0590 & 0.3031 & 0.0031 & 0.1073 & 0.0013 & 1728 & 11 & 1707 & 15 & 1754 & 1297 \\
\hline $1-9$ & TR, & 737 & 0.4179 & 0.1209 & 0.90 & 1.5648 & 0.0535 & 0.1304 & 0.0040 & 0.0871 & 0.0012 & 956 & 21 & 790 & 23 & 1362 & 1358 \\
\hline $1-10 a$ & $\mathrm{~S}$, el & 198 & 0.1712 & 0.0495 & 0.24 & 4.2098 & 0.0450 & 0.2896 & 0.0 & 0.1054 & 0.0013 & 1676 & 9 & 1640 & 17 & 1722 & 1295 \\
\hline $1-10 b$ & $\mathrm{~S}, \mathrm{c}$ & 114 & .3500 & 0.1012 & 0.89 & 3.7245 & 0.0599 & 0.2671 & 0.00 & 0.1011 & 0.0016 & 1577 & 13 & 1526 & 20 & 1645 & 1593 \\
\hline $1-11 a$ & $\mathrm{~S}(20 \times 20)$, euh, tip & 274 & .2339 & 0.0676 & 5.62 & 3.2432 & 0.16 & 0.2365 & 0.00 & 0.0995 & 0.0033 & 1468 & 40 & 1368 & 27 & 1614 & 3285 \\
\hline $11 \mathrm{~b}$ & $\mathrm{~S}(20 \times 20)$, int & 191 & 0.2189 & 0.0633 & 0.39 & 4.1622 & 0.0649 & 0.2959 & 0.0040 & 0.1020 & 0.0015 & 1667 & 13 & 1671 & 20 & 1661 & 14101 \\
\hline $1-12$ & $\mathrm{~S}, \mathrm{p}$, core & 329 & 11 & 0.0900 & 0.20 & 4.2192 & 0.0686 & 0.2961 & 0.0042 & 0.1033 & 0.0011 & 1678 & 13 & 1672 & 21 & 1685 & 1099 \\
\hline $1-13$ & LR, elong, core/int & 229 & 306 & 0.0956 & 2.59 & 4.6710 & 0.0849 & 0.3102 & 0.0043 & 0.1092 & 0.0018 & 1762 & 15 & 1742 & 21 & 1786 & 1597 \\
\hline $1-14 \mathrm{a}$ & $\mathrm{TR}, \mathrm{p}$, int & 177 & 39 & 399 & 2.60 & 5.0393 & 0.14 & 0.3293 & 0.0 & 10 & 0.0 & 1826 & 24 & 1835 & 19 & 1816 & 24101 \\
\hline $1-14 b$ & $\mathrm{~S}$, edge & 128 & 0.3731 & 0.1076 & 0.90 & 4.0341 & & 910 & & & & 1641 & 49 & 1647 & 28 & 1634 & 40101 \\
\hline $1-15$ & $\mathrm{~S}(20 \times 20)$, core & 160 & 0.3276 & 0.0987 & 0.12 & 3.9970 & & 10 & & & & 1634 & 49 & 1647 & 28 & 1617 & 41102 \\
\hline $1-16$ & TR, $\mathrm{p}$, core & 78 & 0.2899 & 0.0838 & 8.24 & 4.0876 & 0.1020 & & & & & 16 & 20 & 1647 & 28 & 1657 & 2699 \\
\hline $1-17$ & $\mathrm{~S}, \mathrm{p}$, core & 57 & 0.0347 & 0.0100 & 8.95 & 4.4155 & 0.1065 & 0.2876 & 55 & & & 1 & 20 & 1629 & 27 & 1822 & 24 \\
\hline $1-18 a$ & $\mathrm{~s}, \mathrm{p}$, & 978 & 0.1565 & 0.0457 & 1.44 & 4.0543 & 0.1028 & 0.2893 & 0.0061 & 0.1 & 0.0 & 45 & 21 & 1638 & 30 & 1654 & 13 \\
\hline $1-19 a$ & $\mathrm{~S}$, elong, int/edge & 950 & 0.2527 & 0.0731 & 2.45 & 3.2347 & 0.0865 & 0.2291 & 0.0065 & 0.1 & 0.0026 & 1466 & 21 & 1330 & 34 & 1668 & 24 \\
\hline $1-20$ & LR, elong, int & 1255 & 0.2280 & 0.0659 & 2.05 & 2.2016 & 0.0448 & 13 & 0.0027 & 0.0932 & 0.0012 & 1182 & 14 & 1019 & 15 & 1493 & 12 \\
\hline $1-21$ & LR, elong, core/int & 4096 & 0.2991 & 0.0865 & 3.56 & 1.0268 & 0.0487 & 0.1126 & 0.0021 & 0.0662 & 0.0023 & 717 & 24 & 688 & 12 & 811 & $37 \quad 85$ \\
\hline $1-22$ & $\mathrm{TR}$, elong, core & 398 & 0.3091 & 0.0894 & 0.27 & 4.1070 & 0.0652 & 0.2931 & 0.0040 & 0.1016 & 0.0012 & 1656 & 13 & 1657 & 20 & 1654 & 12100 \\
\hline $1-23$ & $\mathrm{~S}(20 \times 20), \mathrm{p}$, core & 345 & 0.2194 & 0.0631 & 0.49 & 4.0740 & 0.0633 & 0.2892 & 0.0032 & 0.1022 & 0.0 & 1649 & 13 & 1638 & 16 & 1664 & 1198 \\
\hline $1-24$ & $\mathrm{~S}(20 \times 20), \mathrm{p}$, core & 400 & 0.2428 & 0.0702 & 0.49 & 4.1847 & 0.0495 & 0.2957 & 0.0032 & 0.1 & 0.0009 & 1671 & 10 & 1670 & 16 & 1672 & 9100 \\
\hline $1-25$ & $\mathrm{~S}(20 \times 20)$, elong, core & 179 & 0.4327 & 0.1251 & 0.92 & 5.1604 & 0.1519 & 0.3294 & 0.0040 & 0.1136 & 0.0030 & 1846 & 25 & 1836 & 19 & 1858 & $24 \quad 99$ \\
\hline $1-26$ & $\mathrm{~S}$, elong, core & 255 & 0.3080 & 0.0891 & 2.98 & 4.7267 & 0.1366 & 0.3164 & 0.0038 & 0.1084 & 0.0028 & 1772 & 24 & 1772 & 18 & 1772 & 24100 \\
\hline $1-27$ & $\mathrm{~S}, \mathrm{p}, \mathrm{c}$ & 535 & 0.2822 & 0.0816 & 4.39 & 1.8291 & 0.0487 & 0.1622 & 0.0063 & 0.0818 & 0.0027 & 1056 & 17 & 969 & 35 & 1241 & $32 \quad 78$ \\
\hline $1-28 a$ & $\mathrm{~S}, \mathrm{p}$ & 432 & 0.2595 & 0.0750 & 0.16 & 4.0140 & 0.0495 & 0.2902 & 0.0034 & 0.1003 & 0.0011 & 1637 & 10 & 1642 & 17 & 1630 & 12101 \\
\hline $1-28 b$ & $\mathrm{~S}(20$ & 371 & 0.3125 & 0.0904 & 0.52 & 4.0799 & 0.0552 & 0.2904 & 0.0032 & 0.1019 & 0.0013 & 1650 & 11 & 1644 & 16 & 1659 & $12 \quad 99$ \\
\hline $1-30 a$ & , p, edge & 267 & 0.2343 & 0.0678 & 0.08 & 4.1843 & 0.0671 & 0.2978 & 0.0035 & 0.1 & 0.0013 & 1671 & 13 & 1681 & 17 & 1659 & 12101 \\
\hline $1-30 b$ & $\mathrm{~S}, \mathrm{p}$ & 269 & 0.1770 & 0.0512 & 0.46 & 4.3328 & 0.0509 & 0.3087 & 0.0031 & 0.1018 & 0.0011 & 1700 & 10 & 1734 & 15 & 1657 & 10105 \\
\hline $1-31$ & , $p$, int/tip & 345 & 0.2879 & 0.0833 & 0.13 & 4.0430 & 0.0646 & 0.2888 & 0.0033 & 0.1015 & 0.0019 & 1643 & 13 & 1636 & 16 & 1652 & 1899 \\
\hline $1-32$ & LR, & 421 & 0.2170 & 0.0627 & 1.42 & 3.9441 & 0.0657 & 0.2864 & 0.0052 & 0.0999 & 0.0014 & 1623 & 13 & 1624 & 26 & 1622 & 14100 \\
\hline $2-18 b$ & $\mathrm{~S}(2$ & 234 & 0.2325 & 0.0672 & 0.24 & 4.4516 & 0.0697 & 0.2965 & 0.0033 & 0.1089 & 0.0015 & 1722 & 13 & 1674 & 16 & 1781 & $13 \quad 94$ \\
\hline $2-33$ & int & 244 & 0.1 & 0.0488 & 0.02 & 3.9728 & 0.0472 & 0.2879 & 0.00 & 0.10 & 0.0 & 1629 & 10 & 1631 & 15 & 1625 & 10100 \\
\hline $2-34$ & $\mathrm{TR}$, & 298 & 0.2554 & 0.0738 & 0.11 & 4.0780 & 0.0590 & 0.2915 & 0.00 & 0.10 & 0.0 & 1650 & 12 & 1649 & 17 & 1651 & 12100 \\
\hline & & 76 & 0.0269 & 0.0078 & 9.11 & 4.9741 & 0.1200 & 0.3295 & 0.00 & 0.1095 & 0.0 & 1815 & 20 & 1836 & 30 & 1791 & 24103 \\
\hline $2-35$ & LR, elong & 225 & 0.1764 & 0.0514 & 1.80 & 4.1199 & 0.1044 & 0.2947 & 0.00 & 0.1014 & & 1658 & 21 & 1665 & 31 & 1650 & 13101 \\
\hline $2-6 c$ & $\mathrm{~S}$, elong, tip & 223 & 0.2317 & 0.0667 & 0.42 & 4.1217 & 0.0640 & 0.2924 & 0.0033 & 0.1022 & 0.0012 & 1659 & 13 & 1654 & 16 & 1665 & 1199 \\
\hline
\end{tabular}

\footnotetext{
${ }^{1}$ Analysis pattern refers to the shape of the laser raster (LR: line raster, TR: triangular raster, S: $30 \times 30 \mu \mathrm{m}$ square raster).

${ }^{2}$ Description of zircon morphology and position of analysis in grain (elong: elongate habit, p: prismatic crystal). All laser analyses are described in terms of their relative position within the zircon, i.e., tip, core, edge (with line raster) or intermediate (int) areas. Analyses with the same spot \# followed by a letter (e.g., 1-4a, and 1-4b) indicates multiple analyses of a single grain of zircon.

${ }^{3}$ Calibrated against zircon standard 91500 assuming $81.5 \mathrm{ppm} U$ (Wiedenbeck et al. 1995). Errors in measurements of U concentration are about $\pm 10 \%$. ${ }^{4} \mathrm{f} 206 \%=\%$ of common ${ }^{206} \mathrm{~Pb}$ in sample.

The values of all ratios are corrected for blank, residual laser-induced fractionation and mass discrimination. Values of U/Pb ratios and ages are corrected for common $\mathrm{Pb}$ using the ${ }^{232} \mathrm{Th} /{ }^{238} \mathrm{U}-{ }^{208} \mathrm{~Pb} /{ }^{206} \mathrm{~Pb}$ method (Compston et al. 1984). All errors are quoted at the $1 \sigma$ level. \%conc: concordance of the analysis calculated as $\left({ }^{206} \mathrm{~Pb} /{ }^{238} \mathrm{U}\right.$ age $) /\left({ }^{207} \mathrm{~Pb} /{ }^{206} \mathrm{~Pb}\right.$ age $) \times 100$.
}

it has the advantage that inheritance seems to be nonexistent (von Blanckenburg 1992, Barth et al. 1994). Two major problems are encountered, however, when trying to date allanite that make this mineral more difficult to date compared to, for example, zircon or monazite. Firstly, allanite contains elevated Th and U contents, ranging from $1000 \mathrm{ppm}$ to $2 \mathrm{wt} \%$ and $50 \mathrm{ppm}$ to $0.5 \mathrm{wt} \%$, respectively (e.g., Heaman \& Parrish 1991,
Bingen et al. 1996). Such contents of these radioactive elements can lead to radiation-induced damage, which in turn can induce significant loss of $\mathrm{Pb}$ and alteration of metamict crystals. In addition, allanite forms part of the epidote series of minerals (Deer et al. 1992), and single grains are typically complexly zoned, with endmember compositions ranging from U-Th-REE-rich to $\mathrm{Ca}-\mathrm{Fe}-$ rich being present. The former will be more 

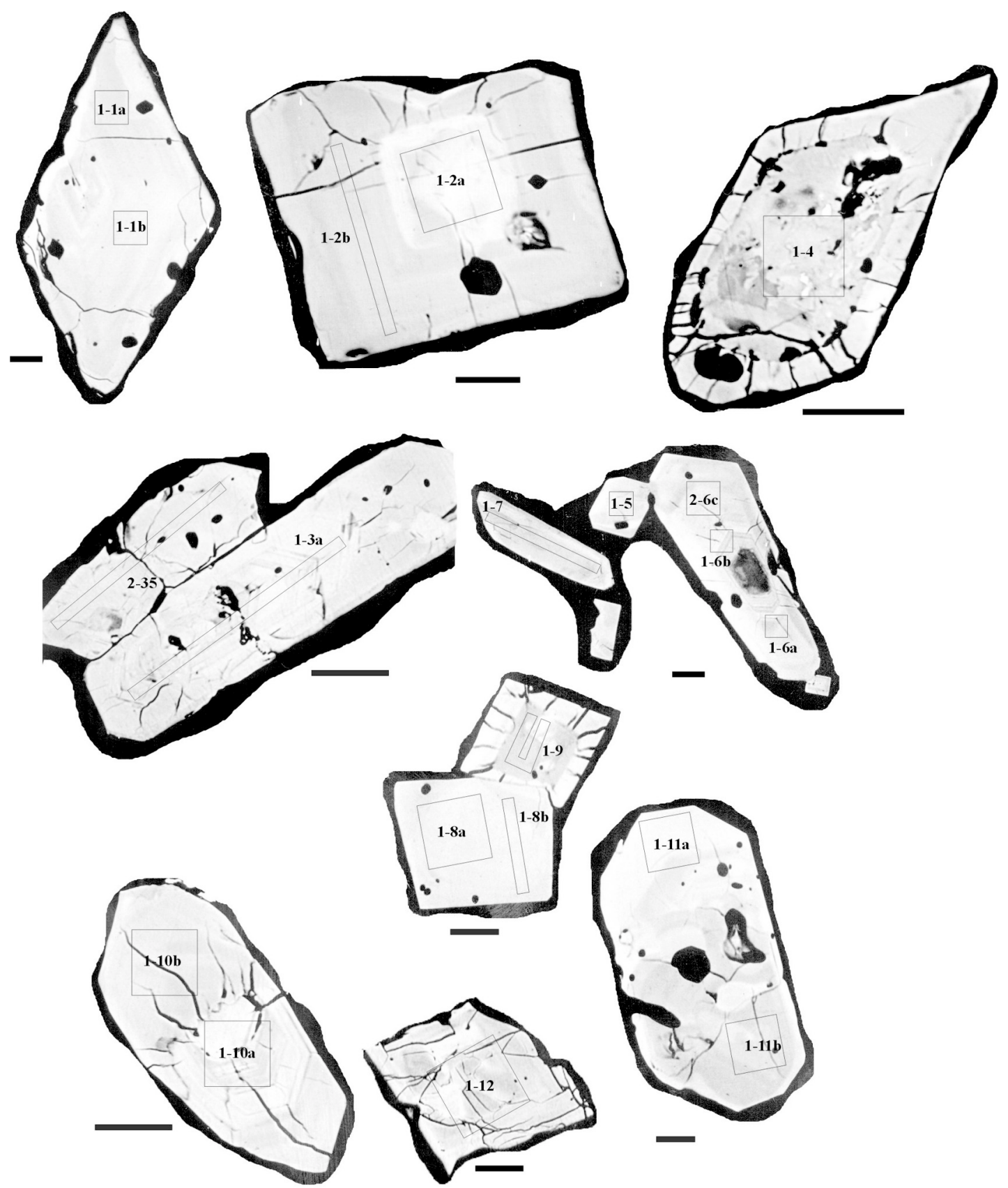

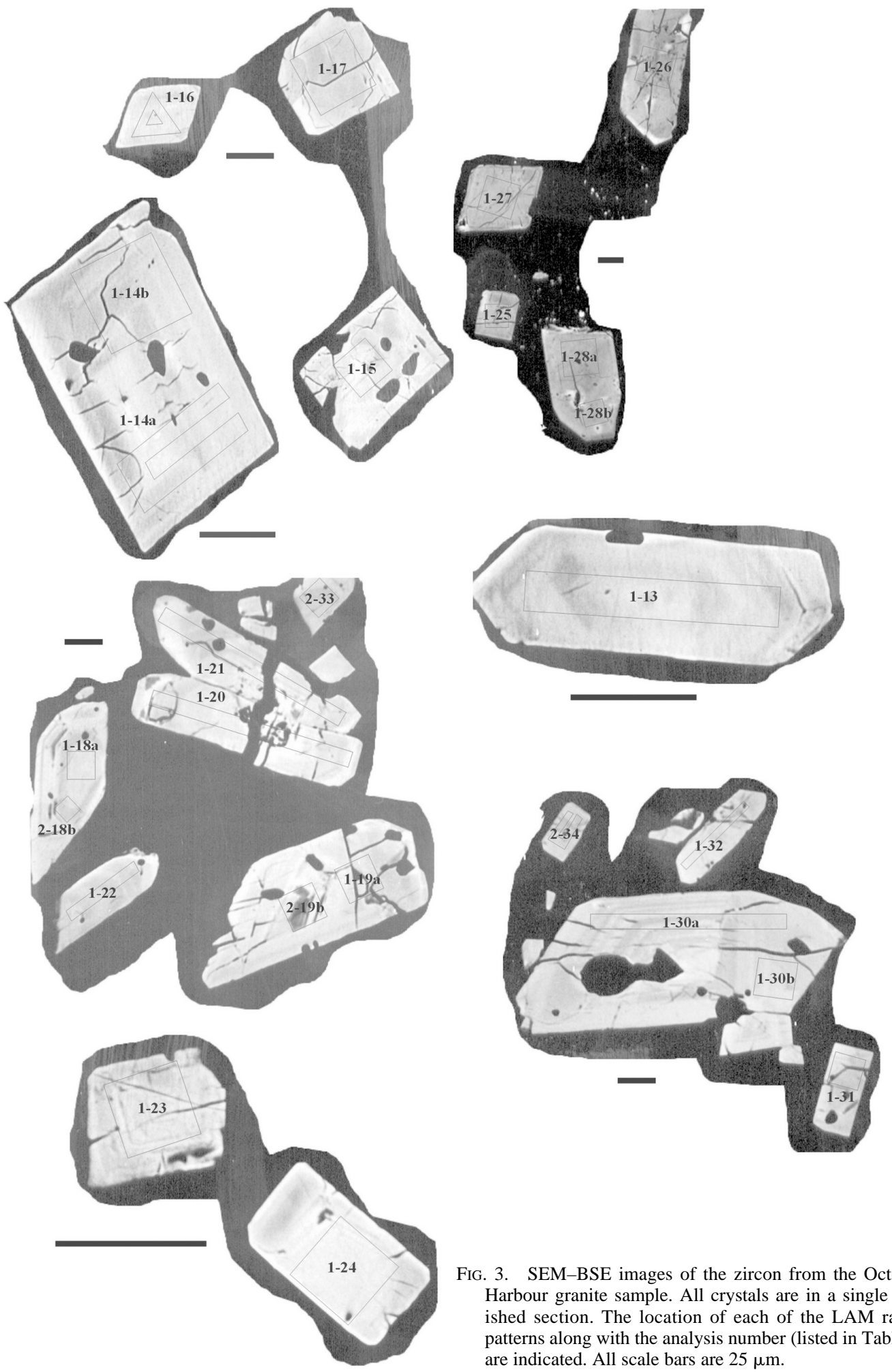

FIG. 3. SEM-BSE images of the zircon from the October Harbour granite sample. All crystals are in a single polished section. The location of each of the LAM raster patterns along with the analysis number (listed in Table 2) are indicated. All scale bars are $25 \mu \mathrm{m}$. 

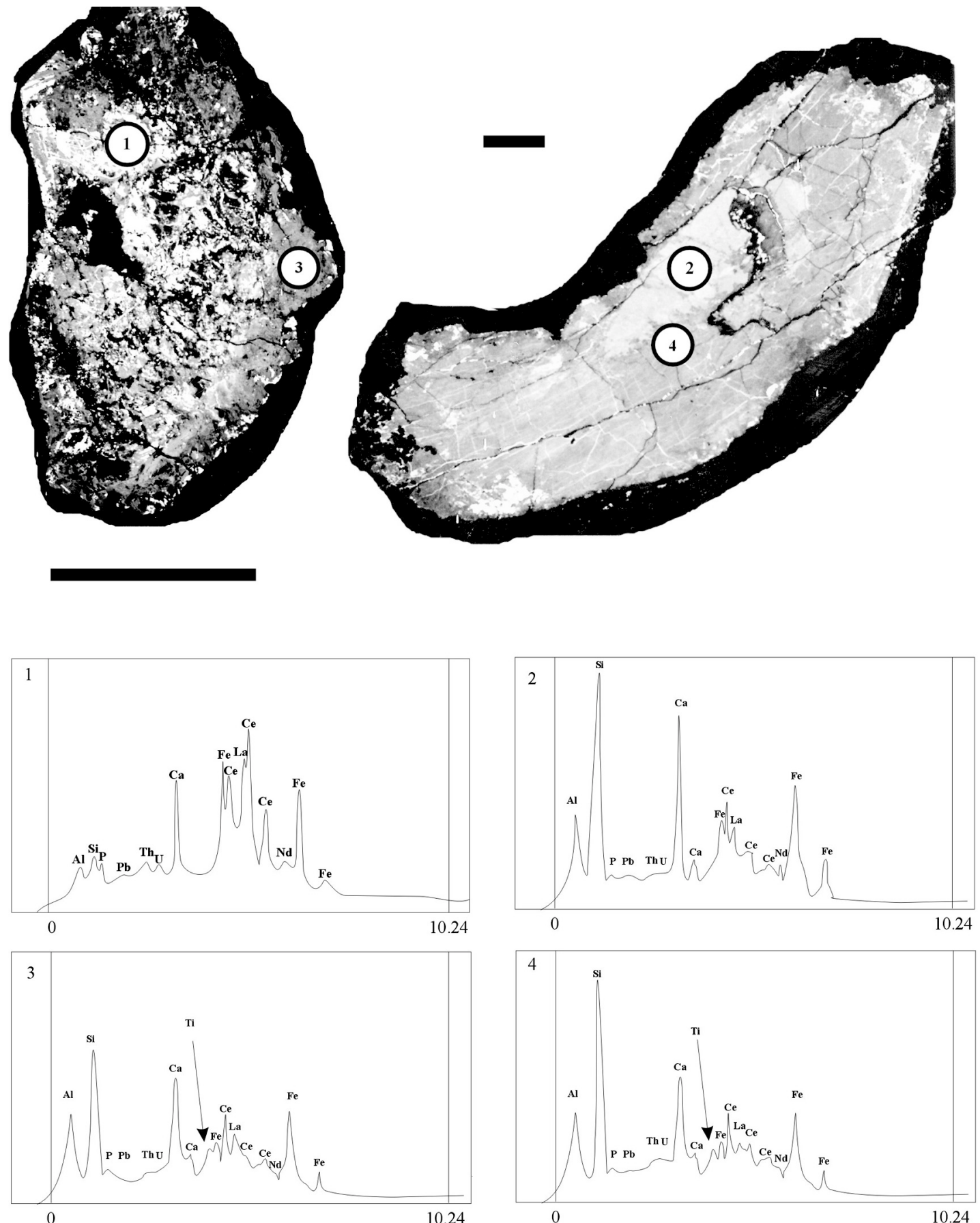

FIG. 4. SEM-BSE images of two large crystals of allanite in the October Harbour granite sample. The crystals are located in the same section as the zircon grains shown in Figure 2. The location of the points analyzed by energy-dispersion spectroscopy are shown, with the corresponding spectra displayed below. Scale bars are $250 \mu \mathrm{m}$. 
prone to being metamict, whereas the epidote end-members contain larger amounts of common $\mathrm{Pb}$. In short, allanite is difficult to date even on a single-grain basis. In situ dating using SIMS would appear to offer some solutions to these problems, but, unfortunately, matrix effects require an external standard and complex datareduction procedures that limit the precision to about 10\% (Catlos et al. 2000). Unlike SIMS, the LAM-ICPMS appears not to suffer from the severe matrix-induced effects, but there is a corresponding loss of spatial resolution (Mason \& Mank 2001).

Two very large crystals of allanite in the October Harbour granite were imaged and targeted for LAMICP-MS analysis. In order to limit analytical complications caused by high contents of common $\mathrm{Pb}$ (epidote domains), or high-Th and high-U (metamict) areas, energy-dispersion X-ray (EDX) spectra were collected on areas with contrasting BSE emission (Fig. 4) prior to LAM-ICP-MS analysis. The brightest zones in the BSE images, labeled as spectrum 1 in Figure 4, yield EDX spectra with low $\mathrm{Al} K \alpha$ and $\mathrm{Si} K \alpha$ peaks. The spectra also display multiple overlapping peaks in the $4.8-7.65 \mathrm{keV}$, typical of high- $R E E$ content, with $\mathrm{Ce} L \alpha$ and $\mathrm{La} L \alpha$ peaks resolvable. The $M \alpha$ peaks at 2.991 and $3.165 \mathrm{keV}$ indicate high $\mathrm{U}$ and Th contents, respectively; multiple Fe and $\mathrm{Ca}$ peaks also are present in the EDX spectra. The elevated $\mathrm{Th}$ and $\mathrm{U}$ contents produce a correspondingly high $\mathrm{Pb} M \alpha$ peak, which is just detectable at $2.342 \mathrm{keV}$. The intermediate zones (labeled 2 in Fig. 4) in the BSE images, which include the core of the largest crystal, display the largest $\mathrm{CaK} \alpha$ peak at $3.69 \mathrm{keV}$ of any zone, along with much larger and better resolved $\mathrm{Al} K \alpha$ and $\mathrm{Si} K \alpha$ peaks, and smaller $R E E$ and Fe peaks than the bright zones. The darkest zones in BSE images, spectra 3 and 4 in Figure 4, display the TiK $\alpha$ peak at $4.508 \mathrm{keV}$. The $\mathrm{U} M \alpha$ and $\mathrm{Th} M \alpha$ peaks are lower in intensity, and consequently the $\mathrm{PbM} \alpha$ peak is no longer detectable. The BSE images thus record differences in REE, $\mathrm{U}, \mathrm{Th}$, $\mathrm{Fe}$ and $\mathrm{Ca}$ contents among zones in these crystals. Allanite and epidote are mainly related by the substitution of $R E E$ and $\mathrm{Fe}^{2+}$ (allanite) for Ca and $\mathrm{Fe}^{3+}$ (Deer $e t$ al. 1992). Thus, the zones richest in $R E E$, Th, U represent the allanite, and the intermediate zones with high Ca contents represent the more epidote-rich domains. The LAM-ICP-MS analyses of these crystals were carried out on clean, crack-free areas of the sample located within these zones, as described in Table 2.

\section{Results From The October Harbor Granite}

\section{Zircon ages}

The LAM-ICP-MS-derived U-Th-Pb data on zircon are listed in Table 1 and plotted in Figure 5. Analytical uncertainties are shown at the $1 \sigma$ level, and final ages are quoted at the $95 \%$ confidence interval. The majority of analyses yield data that cluster between 1600 and $1850 \mathrm{Ma}$. Nine analyses gave discordant points, which define a discordia line from the 1600-1850 Ma age range down to $c a$. $400 \mathrm{Ma}$. These points represent either high-U zircon cores (700-4000 ppm U) that have undergone severe loss in $\mathrm{Pb}$ due to radiation damage, or elongate crystals, which appear to have suffered loss in $\mathrm{Pb}$ due their high ratio of surface area to volume. Twenty-five concordant points gave a weighted mean ${ }^{207} \mathrm{~Pb} /{ }^{206} \mathrm{~Pb}$ age of $1657.3 \pm 10 \mathrm{Ma}(\mathrm{MSWD}=0.77)$. The time-resolved signals for these analyses show no evidence of mixed values, and almost all points correspond to oscillatory zoned zircon. Some of the data points derived from zircon cores, which display evidence of resorption (e.g., 1-2a and 1-11b), gave the same age as the overgrowths.

Eleven concordant to slightly discordant analyses yield older ${ }^{207} \mathrm{~Pb} /{ }^{206} \mathrm{~Pb}$ ages, between 1700 and 1850 Ma. Of these, three analyses are concordant at 1800$1850 \mathrm{Ma}$, and a single point is concordant at $1772 \mathrm{Ma}$. There is no clear pattern to these older components, with both cores of elongate crystals (e.g., 1-10a and 1-6a) and even whole prismatic crystals (e.g., 1-8a and 8b) yielding older ages. These results almost certainly represent inherited crystals from the older (1770-1900 Ma) Paleoproterozoic rocks that are abundant in the Makkovik Province (Schärer et al. 1988, Kerr et al. 1992, Ketchum et al. 2001a, b). Such a conclusion is to be expected in view of the xenolith-rich nature of the October Harbour granite, the xenoliths being part of the ca. 1860 Ma Upper Aillik Group.

The data and textural information suggest a complicated relationship between the incorporation of xenocrysts, new growth of magmatic crystals, resorption and regrowth of the zircon in this rock. The age of the granite can be constrained by the data to be $1657 \pm$ $10 \mathrm{Ma}$, but if all the points are regressed to calculate the apparent age, the result is a Model-2 solution, in which the errors are equally weighted (Ludwig 1999), with intercept ages of $1710 \pm 31$ and $410 \pm 140 \mathrm{Ma}$ (MSWD $=6.2$ ). The upper intercept age of $c a$. $1710 \mathrm{Ma}$ is clearly a mixture of older inheritance and $\mathrm{Pb}$ loss, but is within error of the age of the Cape Strawberry Granite (1719 \pm $3 \mathrm{Ma}$ ) and other apparently related late Makkovikian intrusions (1716 $\pm 1 \mathrm{Ma}$; Ketchum et al. 2001a). After careful evaluation of the LAM-ICP-MS U-Th-Pb ages on zircon, however, the October Harbour Granite is more likely related to the abundant and spatially close ca. 1650 Ma igneous bodies in the southern Makkovik Province (Schärer et al. 1988, Kerr et al. 1992, Wilton 1996).

\section{Allanite ages}

The LAM-ICP-MS U-Th-Pb data on allanite are listed on Table 2 and shown in Figure 6. Analytical uncertainties are shown at the $1 \sigma$ level, and final ages are quoted at the $95 \%$ confidence interval. Sixteen of the 22 analyses from the larger crystal were broadly concordant in their ${ }^{206} \mathrm{~Pb} /{ }^{238} \mathrm{U}$ and ${ }^{208} \mathrm{~Pb}^{/ 232} \mathrm{Th}$ ages, and 
TABLE 2. LAM-ICP-MS DATA ON ALLANITE, OCTOBER HARBOUR GRANITE, CENTRAL COASTAL LABRADOR

\begin{tabular}{|c|c|c|c|c|c|c|c|c|c|c|c|c|c|c|c|}
\hline \multirow[b]{2}{*}{$\begin{array}{l}\text { Spot } \\
\#\end{array}$} & \multirow[b]{2}{*}{$\begin{array}{l}\text { Analysis pattern } 1 \\
\text { and description }\end{array}$} & \multirow[b]{2}{*}{ 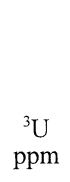 } & \multirow[b]{2}{*}{$\frac{{ }^{232} \mathrm{Th}}{{ }^{238} \mathrm{U}}$} & \multirow[b]{2}{*}{${ }^{206} \frac{\mathrm{Pb}}{\mathrm{Pb}}$} & \multirow[b]{2}{*}{ \pm} & \multirow[b]{2}{*}{$\begin{array}{c}{ }^{4} \mathrm{f} 206 \\
\%\end{array}$} & \multicolumn{4}{|c|}{$\begin{array}{c}\text { Measured values } \\
\text { (corrected for common } \mathrm{Pb} \text { ) }\end{array}$} & \multicolumn{4}{|c|}{$\begin{array}{l}\text { Apparent ages } \\
\mathrm{Ma}\end{array}$} & \multirow[b]{2}{*}{$\begin{array}{r}\% \\
\text { conc }\end{array}$} \\
\hline & & & & & & & ${ }^{232} 2 \mathrm{~Pb}$ & \pm & ${ }^{2306} \mathrm{~Pb}$ & \pm & ${ }^{206} \mathrm{~Pb}$ & \pm & ${ }^{208} \frac{\mathrm{Pb}}{\mathrm{Th}}$ & & \\
\hline $1-1$ & ge & 96 & 4.84 & 10800 & 0159 & 0.76 & 0.07260 & 0.00216 & 0.24218 & 0 & 1398 & 57 & 1416 & 42 & 99 \\
\hline $1-2$ & $(2$ & 144 & 90.10 & 09955 & 0091 & 0.21 & 0.08463 & 0.00128 & 0.28538 & 0.00927 & 1618 & 53 & 1641 & 25 & 99 \\
\hline $1-3$ & ), edge & 122 & 102.12 & 301 & 0127 & 0.19 & 0.08266 & 0.00128 & 6561 & & 1519 & 51 & 1604 & & 95 \\
\hline $1-4$ & $(40 \times 40)$, edge & 142 & 96.20 & 10019 & .00094 & 0.14 & 0.07762 & 0.00084 & 0.23002 & 0.00576 & 1335 & 33 & 1510 & 10 & 88 \\
\hline $1-5$ & $(40 \times 40)$, edge & 136 & 94.52 & 0.10194 & 0.00074 & 0.06 & 0.08694 & 0.00078 & 0.28616 & 0.00461 & 1622 & 26 & 1684 & 15 & 96 \\
\hline $1-6$ & bright & 442 & 31.22 & 3 & 0093 & 1.38 & 0.06188 & 0.00080 & 92 & 5 & 1164 & 26 & 1213 & 16 & 96 \\
\hline $1-7$ & bright & 395 & 34.84 & 0.08899 & .00090 & 1.43 & 0.06342 & 0.00201 & 81 & & 1131 & 20 & 1242 & 39 & 91 \\
\hline $1-8$ & $(40 \times 40)$,int, bright & 135 & 41.98 & 0.09024 & 0.00202 & 1.29 & 0.07891 & 0.00202 & 0.25343 & 0. & 1456 & 51 & 1534 & 39 & 95 \\
\hline $1-9$ & & 145 & 36.80 & 1 & 7 & 1.97 & 0.08 & 0.00180 & 0.2 & 0.00 & 1536 & 49 & 1565 & 35 & 98 \\
\hline $1-10$ & $(40$ & 132 & 45.81 & 08969 & 00198 & 1.35 & 0.08108 & 81 & 8107 & & 1597 & 44 & 1575 & 35 & 101 \\
\hline & $(40 x$ & 142 & 69.02 & & & 1.32 & 0.0 & 0.0 & 0.2 & & 94 & 55 & & 26 & 101 \\
\hline & & 130 & 73.73 & 0.10093 & .00102 & 0.05 & 0.06272 & 0.00136 & 0.22019 & 0.0 & 1283 & 27 & 1229 & 27 & 104 \\
\hline & , dark & 70 & 69.71 & 0.10886 & 0.00128 & 0.86 & 0.0 & 0.00102 & 0.28310 & 0.0 & 1607 & 42 & 1612 & 20 & 100 \\
\hline & 0 ), core, dark & 67 & & & & 0.03 & 0.0 & 0.0 & & & 1622 & 50 & 1631 & 1 & 99 \\
\hline & & 71 & 75.57 & 8 & 19 & 0.60 & 0.0 & 0.00088 & 0.28564 & & 1620 & 39 & 1670 & 17 & 97 \\
\hline $1-16$ & $(40 \times 40)$, core, dark & 81 & 81.13 & 0.10107 & 0.00129 & 0.04 & 0.08473 & 0.00099 & 0.28851 & 0.0 & 1634 & 62 & 1643 & 19 & 99 \\
\hline & $(40 \times 40)$,core, dark & 79 & 58.76 & & & 0.43 & 0.08216 & 0.00141 & 0.23153 & & 1342 & 64 & 5 & 2 & 84 \\
\hline $1-1$ & $(4$ & 84 & 62.16 & 7 & 29 & 1.09 & 0.08518 & 0.0 & 0.28341 & & 1608 & 41 & 1651 & 21 & 97 \\
\hline $1-1$ & $(40 \times 40), \mathrm{cc}$ & 92 & 62.25 & 0.09678 & 0.00112 & 0.53 & 0.08373 & 0.00134 & 0.28854 & 0.00931 & 1634 & 53 & 1624 & 26 & 101 \\
\hline & & 83 & 62.46 & & 0.00130 & 2.23 & 0.08478 & 0.00180 & 0.28232 & & 1603 & 48 & & 3. & 98 \\
\hline & & 93 & 59.16 & & 0 & 2.28 & 0.0 & 0.0 & 0.28166 & & 1600 & 39 & 16 & 23 & 98 \\
\hline $1-22$ & $(40 \times 40), \mathrm{co}$ & 86 & 62.83 & 0.11547 & 0.00111 & 1.62 & 0.08299 & 0.00161 & 0.26855 & 0.01224 & 1533 & 70 & 1611 & 31 & 95 \\
\hline & & 473 & & & & 13.80 & & & & & 426 & 19 & 461 & & 92 \\
\hline $2-2$ & & 71 & & & & 10. & 0.035 & 0.0 & & 0.0 & 532 & 45 & 708 & 17 & 75 \\
\hline $2-3$ & $\times 40$ ), core, bright & 138 & 31.40 & 0.15453 & 0.00170 & 6.14 & 0.06088 & 0.00131 & 0.14530 & 0.00932 & 875 & 56 & 1194 & 26 & 73 \\
\hline $2-4$ & $(40 \times 40)$,int, dark & 250 & 19.96 & 0.41927 & 0.003143 & 36.71 & 0.02560 & 0.00716 & 0.06757 & 0.00206 & 422 & 13 & 511 & 143 & 83 \\
\hline
\end{tabular}

${ }^{1}$ All analyses of allanite were carried out using square raster patterns, with size shown in parentheses.

2 Description of area within the two large crystals analyzed. Bright and dark refers to intensity of BSE emission.

${ }^{3}$ Calibrated against allanite AVC-1 from the Atesina volcanic complex, assuming a U concentration of 116.25 ppm (Barth et al. 1994).

Errors in measurements of $U$ concentrations are about $\pm 25 \%$ owing to variation in $U$ content within the standard.

${ }^{4} \mathrm{f} 206 \%=\%$ of common ${ }^{206} \mathrm{~Pb}$ in sample.

The values of all ratios are corrected for blank, residual laser-induced fractionation and mass discrimination. Values of ${ }^{206} \mathrm{~Pb} /{ }^{238} \mathrm{U}$ and ${ }^{208} \mathrm{~Pb} /{ }^{232} \mathrm{Th}$ ratios and ages are corrected for common $\mathrm{Pb}$ using the ${ }^{207} \mathrm{~Pb} /{ }^{206} \mathrm{~Pb}$ method described in Williams (1996). All errors are quoted at the $1 \sigma$ level. \%conc $=$ concordance of the analysis calculated as $\left({ }^{208} \mathrm{~Pb} /{ }^{232} \mathrm{Th}\right.$ age $) /\left({ }^{206} \mathrm{~Pb} /{ }^{238} \mathrm{U}\right.$ age $) \times 100$.

cluster in the age range 1580-1660 Ma. The remaining data from this crystal, and all four analyses from the smaller crystal (2-1 to $2-4)$, indicate a younger age, but still broadly concordant. Although it is not clear what these younger ages represent, it is likely that they are affected by $\mathrm{Pb}$-loss events, as suggested by the results on zircon. These younger allanite-derived ages may record small-scale disruption of the U-Th-Pb systematics of some grains due to regional events such as the Grenvillian Orogeny at $c a .1000 \mathrm{Ma}$ and the Appalachian-Caledonian orogeny at $c a$. $450 \mathrm{Ma}$. There is no evidence of inheritance in the allanite crystals studied. The weighted mean ${ }^{208} \mathrm{~Pb} /{ }^{232} \mathrm{Th}$ age, which is the least likely to be affected by common $\mathrm{Pb}$ or $\mathrm{Pb}$ loss (Barth $e t$ al. 1994), is $1635 \pm 17 \mathrm{Ma}(\mathrm{MSWD}=2.1)$. This is within error of the ${ }^{207} \mathrm{~Pb} /{ }^{206} \mathrm{~Pb}$ age yielded by the concordant data-points obtained on zircon and, thus, is also likely representative of the igneous age of the granite. The most reliable data from the allanite come from points located in zones where $\mathrm{Ti}$ was detected by the EDX analysis and which were not enriched in either epidote or allanite end-member components. The allanite-rich, i.e., (Th, $\mathrm{U}$ and REE)-rich, areas yield highly discordant data, and the more epidote-rich, i.e., (Ca and $\mathrm{Fe}$ )rich, areas are generally enriched in common $\mathrm{Pb}$. Even qualitative EDX results on allanite can thus be used to locate zones, which may produce reliable $\mathrm{U}-\mathrm{Th}-\mathrm{Pb}$ isotope data with the LAM-ICP-MS technique. Clearly, both the zircon and allanite data are relatively complex, and both minerals record a long history of events recorded by inherited components (zircon only), crystalgrowth ages, resorption features and Pb-loss events, even in this undeformed granite with an apparently simple magmatic history. 


\section{DisCUSSION}

\section{Summary of in situ $U-T h-P b$ dating} using the LAM-ICP-MS technique

In the present study, we demonstrate the utility of in situ $\mathrm{U}-\mathrm{Th}-\mathrm{Pb}$ dating of zircon-allanite using the LAMICP-MS technique. There was no requirement for mineral separation, dissolution and chemical treatment of the separates, or special preparation of the section to embed standards, as in SIMS dating. The success in dating zircon using the LAM-ICP-MS method has been amply demonstrated in several recent publications (e.g., Belousova et al. 2001, Horn et al. 2000, Knudsen et al. 2001, Košler et al. 2002, White et al. 2001), in which the authors have variously utilized the following techniques that we used in this study:

1) He carrier gas (Loucks et al. 1995, Eggins et al. 1998, Günther \& Heinrich 1999) and small sample-cell design to improve signal response (Bleiner \& Günther 2001).

2) Simultaneous aspiration of solution to correct for mass bias (Chenery \& Cook 1993, Parrish et al. 1999, Horn et al. 2000, Košler et al. 2002).

3) Instrument drift monitored using an external standard (Jackson et al. 1992).
4) The use of a defocused beam (Jackson et al. 1996, Jackson 2001) and slow rastering of sample to reduce inter-elemental fractionation (Parrish et al. 1999).

5) The use of common- $\mathrm{Pb}$ corrections, $\mathrm{a}^{232} \mathrm{Th} /{ }^{238} \mathrm{U}-$ ${ }^{208} \mathrm{~Pb} /{ }^{206} \mathrm{~Pb}$ correction for zircon and a ${ }^{207} \mathrm{~Pb} /{ }^{206} \mathrm{~Pb}$ correction for allanite (Compston et al. 1984).

The result is that single crystals of zircon can be dated using a volume of material less than $30 \times 30 \times$ $10 \mu \mathrm{m}$ with a precision of $2-8 \%(2 \sigma)$. This precision is similar to that encountered with SIMS methods, with about 10 times more material sampled.

For dating allanite, the main problem remains finding areas that are low in common $\mathrm{Pb}$ and high enough in $\mathrm{Th}$ and $\mathrm{U}$ to provide accurate and precise measurements, but not so high as to have caused significant damage to the crystal. This condition appears to have been met in this study by allanite with moderately high $\mathrm{Ti}$ contents and low REE contents (Fig. 4). Although we have not quantified the concentrations of these elements, this qualitative observation may be used to locate zones within allanite crystals that are suitable for LAM-ICPMS dating. In addition, the use of the ${ }^{207} \mathrm{~Pb} / 206 \mathrm{~Pb}$ common- $\mathrm{Pb}$ correction appears to have been successful, even in these older crystals. The resultant precision on ${ }^{208} \mathrm{~Pb} /{ }^{232} \mathrm{Th}$ ages measured using a $40 \times 40 \times 10 \mu \mathrm{m}$ volume is about $2-5 \%(2 \sigma)$. The precision on the ${ }^{206} \mathrm{~Pb} /$

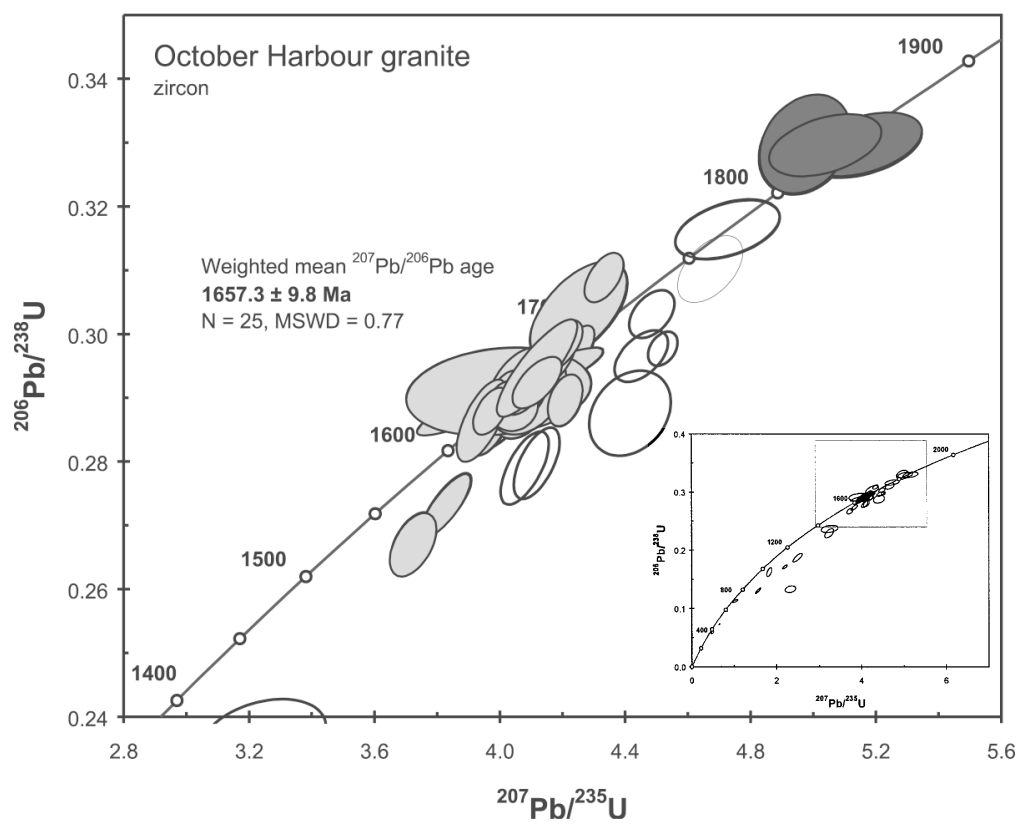

FIG. 5. U-Pb concordia diagrams for the LAM data obtained on zircon from the October Harbour granite. 
${ }^{238} \mathrm{U}$ age is similar, but it is clear from this study, as in previous work (Barth et al. 1994), that the mobility of $\mathrm{U}$ or $\mathrm{Pb}$ (or both) in allanite affects the $\mathrm{U}-\mathrm{Pb}$ system more than the $\mathrm{Th}-\mathrm{Pb}$ system. Thus, for future LAMICP-MS dating projects, the $\mathrm{Th}-\mathrm{Pb}$ ages for allanite should be considered the more accurate, and the corresponding ${ }^{206} \mathrm{~Pb} /{ }^{238} \mathrm{U}$ ages used primarily for checking the concordance.

The pattern of ages recorded by the zircon in the October Harbour granite has implications of wider conceptual significance. The $1719 \pm 3 \mathrm{Ma}$ age for the Strawberry granite (Kerr et al. 1992) is partly supported by an age of $1716 \pm 1$ Ma recorded by monazite from the Blacklers Bight granite in the northern Makkovik Province (Ketchum et al. 2001a). One can certainly argue that multiple concordant data-points from small fractions of material most likely represent the age of the rocks, and the close agreement in age between these two intrusions supports the conclusion that there is a suite of late, postorogenic intrusions in the Makkovik Province (Kerr \& Fryer 1994, Barr et al. 2001). If we take the ages of the Cape Strawberry and Blacklers Bight granite bodies at face value, it is clear from our results that despite the close proximity of the October Harbour granite to the Cape Strawberry Intrusive suite, and their very similar petrological and geochemical characteristics (Gower $e t$ al. 1982), they are clearly unrelated, as the October Harbour granite is at least 70 Ma younger. This fact calls into question the use of geochemical and isotopic data to delineate large-scale igneous suites where clear crosscutting or gradational contacts are not visible. For example, the high $\mathrm{F}$ contents and the trace-element compositions of the Cape Strawberry and Blacklers Bight intrusions suggest that an extensive suite of postMakkovikian intrusions is present in the Makkovik Province (Barr et al. 2001). On the basis of the age of the October Harbour granite reported here, however, this hypothesis is difficult to substantiate. It is clear that more extensive dating of each distinct unit within an apparently related suite of intrusions will be required to fully assess the regional extent of group as a whole. Fortunately, techniques of rapid in situ dating can be incorporated into petrographic studies, as reported here. This approach should allow more effective delineation of suites of rocks, which can then be more selectively sampled for higher-precision dating, if required.

\section{Conclusions}

$\mathrm{U}-\mathrm{Th}-\mathrm{Pb}$ dating of zircon and allanite from the October Harbour granite has been successfully carried out using the latest advances in LAM-ICP-MS methods; the ages derived from allanite match those derived from the more routinely used zircon grains. More detailed analyses of the zircon grains suggest that mixtures of inheritance and newly grown crystals can significantly affect the results, even in a single LAM-ICP-MS analysis of than less than $9000 \mu^{3}$. If moderately large vol-

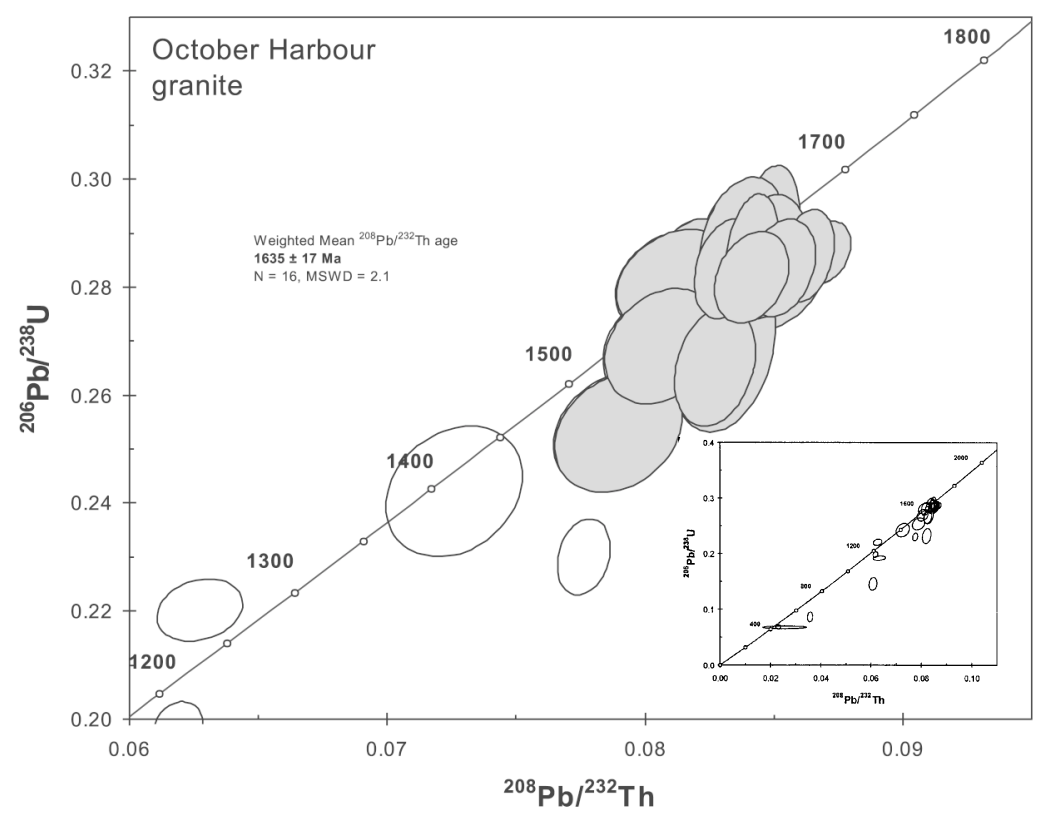

FIG. 6. U-Th-Pb concordia diagrams for the LAM data obtained on allanite from the October Harbour granite. 
umes of a zoned zircon were mixed together, for a standard TIMS analysis, the result would be that these fractions would record the average mixed-age components in the rock. Undetected mixing of different age components may be a more common problem in terranes intruded by multiple large-scale magmatic bodies. In situ LAM-ICP-MS dating of zircon and allanite after preimaging the grains can be used to help eliminate some of the uncertainty involved in dating this type of intrusion. The age of the October Harbour granite (1657 \pm $10 \mathrm{Ma}$ ) is much younger than that measured in the adjacent Cape Strawberry granite. Geochemical data alone thus cannot be routinely used to successfully delineate large-scale igneous bodies in terranes where multiple phases of intrusive activity have occurred. More extensive dating using the LAM-ICP-MS and other rapid in situ methods can be carried out in conjunction with petrographic and geochemical data to remove much of the uncertainty involved in characterizing complex suites of intrusions.

\section{ACKNOWLEDGEMENTS}

The samples were collected as part of a CanadaNewfoundland Mineral Development Agreement set up to examine the metallogeny of the Central Mineral Belt in Labrador; the assistance of the Newfoundland Department of Mines and Energy and the Geological Survey of Canada is gratefully acknowledged. Analytical costs were borne by Wilton's NSERC Operating Grant. Mike Tubrett provided, as always, sublime assistance. The manuscript was improved substantially through reviews by Nuno Machado, John Ketchum, Robert F. Martin and Paul Sylvester.

\section{REFERENCES}

Barr, S.M., White, C.E., Culshaw, N.G. \& Ketchum, J.W.F. (2001): Geology and tectonic setting of Paleoproterozoic granitoid suites in the Island Harbour Bay area, Makkovik Province, Labrador. Can. J. Earth Sci. 38, 441-463.

Barth, S., Oberli, F. \& MeIER, M. (1994): Th-Pb versus U$\mathrm{Pb}$ isotope systematics in allanite from co-genetic rhyolite and granodiorite: implications for geochronology. Earth Planet. Sci. Lett. 124, 149-159.

Belousova, E.A., Griffin, W.L., Shee, S.R., Jackson, S.E. \& O'ReILly S.Y. (2001): Two age populations of zircons from the Timber Creek kimberlites, Northern Territory, as determined by laser-ablation ICP-MS analysis. Aust. J. Earth Sci. 48, 757-765.

Bingen, B., Demaiffe, D. \& Hertogen, J. (1996): Redistribution of rare earth elements, thorium and uranium over accessory minerals in the course of amphibolite to granulite facies metamorphism: the role of apatite and monazite in orthogneisses from southwestern Norway. Geochim. Cosmochim. Acta 60, 1341-1354.
Bleiner, D. \& GÜNTHER, D. (2001): Theoretical description and experimental observation of aerosol transport processes in laser ablation inductively coupled plasma mass spectrometry. J. Anal. Atom. Spectrom. 16, 449-456.

BroskA, I. \& SimAN, P. (1998): The breakdown of monazite in the West-Carpathian Veporic orthogneiss and Tatric granites. Geol. Carphathica 46, 161-167.

Catlos, E.J., Sorensen, S.S. \& Harrison, T.M. (2000): Th-Pb ion-microprobe dating of allanite. Am. Mineral. 85, 633-648.

CHENERy, S. \& Cook, J.M. (1993): Determination of rare earth elements in single mineral grains by laser ablation microprobe - inductively coupled plasma - mass spectrometry preliminary study. J. Anal. Atom. Spectrom. 8, 299-303.

Compston, W. (1999): Geological age by instrumental analysis: the $29^{\text {th }}$ Halimond lecture. Mineral. Mag. 63, 297-311.

Williams, I.S. \& Meyer, C.E. (1984): U-Pb geochronology of zircons from lunar breccia 73217 using a sensitive high mass-resolution ion microprobe. J. Geophys. Res. 89, 525-534.

ConNelly, J.N. (2000): Degree of preservation of igneous zonation in zircon as a signpost for concordancy in $\mathrm{U}-\mathrm{Pb}$ geochronology. Chem. Geol. 172, 25-39.

Corfu, F., Heaman, L.M. \& Rogers, G. (1994): Polymetamorphic evolution of the Lewisian complex, NW Scotland, as recorded by $\mathrm{U}-\mathrm{Pb}$ isotopic compositions of zircon, titanite and rutile. Contrib. Mineral. Petrol. 117, 215-228.

Deer, W.A., Howie, R.A. \& Zussman, J. (1992): An Introduction to the Rock-Forming Minerals ( $2^{\text {nd }}$ ed.). Longman Scientific and Technical, Harlow, U.K.

EgGins, S.M., KinSley, L.P.J. \& Shelley, J.M.M. (1998): Deposition and element fractionation processes during atmospheric pressure laser sampling for analysis by ICP-MS. Appl. Surf. Sci. 129, 278-286.

FenG, R., Machado, N. \& Ludden, J. (1993): Lead geochronology of zircon by laser probe - inductively coupled plasma - mass spectrometry LP-ICP-MS. Geochim. Cosmochim. Acta 57, 3479-3486.

Foster, G., Kinny, P., Vance, D., Prince, C. \& Harris, N. (1999): The significance of monazite U-Th-Pb age data in metamorphic assemblages; a combined study of monazite and garnet chronometry. Earth Planet. Sci. Lett. 181, 327340 .

Fryer, B.J., JACKSON, S.E. \& LONGERICH, H.P. (1993): The application of laser ablation microprobe - inductively coupled plasma - mass spectrometry (LAM-ICP-MS) to insitu (U)-Pb geochronology. Chem. Geol. 109, 1-8.

Gower, C.F., Flanagan, M.J., Kerr, A. \& Bailey, D.G. (1982): Geology of the Kaipokok Bay - Big River area, Central Mineral Belt, Labrador. Nfld. Dep. Mines Energy, Rep. 82-7, 1-77. 
Grove, M. \& Harrison, T.M. (1999): Monazite Th-Pb age depth profiling. Geology 27, 487-490.

GÜNTHER, D. \& HEINRICH, C.A. (1999): Enhanced sensitivity in laser ablation - ICP mass spectrometry using heliumargon mixtures as aerosol carrier. J. Anal. Atom. Spectrom. 14, 1363-1368.

HANCHAR, J.M. \& MiLler, C.F. (1993): Zircon zonation patterns as revealed by cathodophotoluminescence and backscattered electron images: implications for interpretation of complex crustal histories. Chem. Geol. 110, 1-13.

Harrison, T.M., Grove, M., McKeegan, K.D., Coath, C.D., LOVERA, O.M. \& LeForT, P. (1999): Origin and episodic emplacement of the Manaslu Intrusive Complex, Central Himalaya. J. Petrol. 40, 3-19.

HEAman, L.M. \& PARRISH, R.R. (1991): U-Pb geochronology of accessory minerals. In Applications of Radiogenic Isotope Systems to Problems in Geology (L. Heaman \& J. Ludden, eds.). Mineral. Assoc. Can., Short Course Ser. 19, 59-102.

HIRATA, T. (1996): Lead isotopic analyses of NIST standard reference materials using multiple collector inductively coupled plasma mass spectrometry coupled with a modified external correction method for mass discrimination effect. Analyst 121, 1407-1411.

Horn, I., Rudnick, R.L. \& McDonough, W.F. (2000): Precise elemental and isotope ratio measurement by simultaneous solution nebulization and laser ablation - ICP-MS: application to U-Pb geochronology. Chem. Geol. 164, 281-301.

HoskIN, W.O. \& BLACK, L.P. (2000): Metamorphic zircon formation by solid-state recrystallization of protolith igneous zircon. J. Metamorph. Geol. 18, 423-439.

IRELAND, T.R. \& GIBSON, G.M. (1998): SHRIMP monazite and zircon geochronology of high-grade metamorphism in New Zealand. J. Metamorph. Geol. 16, 149-167.

JACKSON, S.E. (2001): The application of Nd:YAG lasers in LA-ICP-MS. In Laser Ablation - ICPMS in the Earth Sciences: Principles and Applications (P. Sylvester, ed.). Mineral. Assoc. Can., Short Course Ser. 29, 29-45.

LONGERICH, H.P., DUNNING, G.R. \& FrYer, B.J. (1992): The application of laser-ablation microprobe - inductively coupled plasma - mass spectrometry LAM-ICPMS to in situ trace element determinations in minerals. Can. Mineral. 30, 1049-1064.

Horn, I. \& DunNing, G.R. (1996): The application of laser ablation microprobe (LAM)-ICP-MS to in situ U-Pb zircon geochronology. J. Conf. Abstr. 1, 283.

KerR, A. \& Fryer, B.J. (1994): The importance of late- and post-orogenic crustal growth in the early Proterozoic: evidence from $\mathrm{Sm}-\mathrm{Nd}$ isotopic studies of igneous rocks in the Makkovik Province, Canada. Earth Planet. Sci. Lett. 25, 71-88.
, Krogh, T.E., CoRfu, F., SChÄRER, U., GANDhI, S.S. \& KwoK, Y.Y. (1992): Episodic early Proterozoic plutonism in the Makkovik Province, Labrador: $\mathrm{U}-\mathrm{Pb}$ geochronological data and geological implications. Can. J. Earth Sci. 29, 1166-1179.

Ryan, B., Gower, C.F. \& Wardle, R.J. (1996): The Makkovik Province: extension of the Ketilidian mobile belt in mainland North America. In Precambrian Crustal Evolution in the North Atlantic Region (T.S. Brewer, ed.). Geol. Soc. London, Spec. Publ. 112, 155-177.

Ketchum, J.W.F., Barr, S.M., Culshaw, N.G. \& White, C.E. (2001a): U-Pb ages of granitoid rocks in the northwestern Makkovik Province, Labrador: evidence for 175 million years of episodic synorogenic and postorogenic plutonism. Can. J. Earth Sci. 38, 359-372.

Culshaw, N.G. \& DunNing, G.R. (1997): U-Pb geochronologic constraints on Paleoproterozoic orogenesis in the northwestern Makkovik Province, Labrador, Canada. Can. J. Earth Sci. 34, 1072-1088.

Jackson, S.E., Culshaw, N.G. \& Barr, S.M. (2001b): Depositional and tectonic setting of the Paleoproterozoic Lower Aillik Group, Makkovik Province, Canada: evolution of a passive margin - foredeep sequence based on petrochemistry and U-Pb (TIMS and LAM-ICP-MS) geochronology. Precamb. Res. 105, 331-356.

KINNY, P.D. \& FRIEND, C.R.L. (1997): U-Pb isotopic evidence for the accretion of different crustal blocks to form the Lewisian complex of northwest Scotland. Contrib. Mineral. Petrol. 129, 326-340.

Knudsen, T.-L, Griffin, W.L., Hartz, E.H., Andresen, A. \& JACKSON, S.E. (2001): In-situ hafnium and lead isotope analyses of detrital zircons from the Devonian sedimentary basin of NE Greenland: a record of repeated crustal reworking. Contrib. Mineral. Petrol. 141, 83-94.

Košler, J., Fonneland, H., Sylvester, P., Tubrett, M. \& Pederson, R.-B. (2002): U-Pb dating of detrital zircons for sediment provenance studies - a comparison of laser ablation ICPMS and SIMS techniques. Chem. Geol. 182, 605-618.

\& SYlVESTER, P. (2003): Present trends and the future of zircon in geochronology: laser ablation ICPMS. In Zircon: Experiments, Isotopes, and Trace Element Investigations (J.M. Hanchar \& P.W.O. Hoskin, eds.). Rev. Mineral. Geochem. (in press).

Li, Xian-Hua, Liang, Xi-Rong, Sun, Min, Guan, Howg \& MALPAS, J. (2001): Precise ${ }^{206} \mathrm{~Pb} /{ }^{238} \mathrm{U}$ age determination on zircons by laser ablation microprobe - inductively coupled plasma - mass spectrometry using continuous linear ablation. Chem. Geol. 175, 209-219.

LOUCKS, R.R., EgGins, S.M., SHELley, L.M.G., KINSLEY, L.P.J. \& WARE, N.G. (1995): Development of the inductivelycoupled-plasma mass spectrometry ultraviolet laser trace- 
element micro-analyzer (ICPMS-ULTEMA). Research School of Earth Sciences, Ann. Rep., 138-140.

LuDwIG, K.R. (1999): IsoplotEx v.2.6. Berkeley Geochronological Center, Spec. Publ. 1a.

Machado, N. \& Simonetti, A. (2001): U-Pb dating and Hf isotopic composition of zircon by laser ablation-MC-ICPMS. In Laser-Ablation - ICPMS in the Earth Sciences: Principles and Applications (P. Sylvester, ed.). Mineral. Assoc. Can., Short Course Ser. 29, 121-146.

Mason, P.R.D. \& MANK, A.J.G. (2001): Depth analysis by laser-ablation ICP-MS. In Laser-Ablation - ICPMS in the Earth Sciences: Principles and Applications (P. Sylvester, ed.). Mineral. Assoc. Can., Short Course Ser. 29, 93-104.

McNaughton, N.J., Rasmussen, B. \& Fletcher, I.R. (1999): SHRIMP uranium-lead dating of diagenetic xenotime in siliciclastic sedimentary rocks. Science $\mathbf{2 8 5}$, 78-80.

Mezger, K. \& KRÖGSTAD, E.J. (1997): Interpretation of discordant U-Pb zircon ages, an evaluation. J. Metamorph. Geol. 15, 127-140.

Parrish, R.R., Nowell, G., Noble, S.R., Horstwood, M., Timmerman, H., Shaw, P. \& Bowen, I.J. (1999): LAPIMMS: a new method of U-Th-Pb geochronology using micro-sampling techniques. J. Conf. Abstr. 4, 799.

Poller, U., Liebetrau, V. \& Todt, W. (1997): U-Pb single zircon dating under cathodoluminescence control (CLCmethod): application to polymetamorphic orthogneisses. Chem. Geol. 139, 287-297.

Pupin, J. (1980): Zircon and granite petrology. Contrib. Mineral. Petrol. 73, 207-220.

REED, S.J.B. (1995): Electron microprobe analysis. In Microprobe Techniques in the Earth Sciences (P.J. Potts, J.F.W. Bowles, S.J.B. Reed \& M.R. Cave, eds.). Mineral. Soc., Monogr. Ser. 6, 49-89.

SchäreR, U., KROGH, T.E., WARdLE, R.J., RYAN, B. \& GANDHI, S.S. (1988): U-Pb ages of early and middle Proterozoic volcanism and metamorphism in the Makkovik Orogen, Labrador. Can. J. Earth Sci. 25, 1098-1107.

Stacey, J.S. \& Kramers, J.D. (1975): Approximation of terrestrial lead isotope evolution by a two-stage model. Earth Planet. Sci. Lett. 26, 207-221.

SteIGer, R.H. \& JÄGER, E. (1977): Subcommission on Geochronology: convention on the use of decay constants in geo- and cosmochronology. Earth Planet. Sci. Lett. 36, 359-362.
STERN, R.A. \& BERMAN, R.G. (2000): Monazite U-Pb and Th$\mathrm{Pb}$ geochronology by ion microprobe with an application to in-situ dating of an Archean metasedimentary rock. Chem. Geol. 172, 113-130.

VANCE, D. \& ThiRwall, M. (2002): An assessment of mass discrimination in MC-ICPMS using Nd isotopes. Chem. Geol. 185, 227-240.

VAVRA, G. (1993): A guide to quantitative morphology of accessory zircon. Chem. Geol. 110, 15-28.

Gebauer, D., Schmid, R. \& Compston, W. (1996): Multiple zircon growth and recrystallization during polyphase Late Carboniferous to Triassic metamorphism in granulites of the Ivrea Zone, (Southern Alps): an ion microprobe (SHRIMP) study. Contrib. Mineral. Petrol. 122, 337-358.

Von Blanckenburg, F. (1992): Combined high-precision chronometry and geochemical tracing using accessory minerals applied to the Central-Alpine Bergell intrusion (central Europe). Chem. Geol. 100, 19-40.

Weidenbeck, M., Allé, P., Corfu, F., Griffin, W.L., Meier, M., Oberli, F., Von Quadt, A., Roddick, J.C. \& SpIEgel, W. (1995): Three natural zircon standards for U-Th-Pb, Lu-Hf, trace-elements and REE analyses. Geostandards Newslett. 19, 1-23.

White, N.M., PARrish, R.R., Bickle, M.J., NAJMAN, Y.M.R., Burbank, D. \& Maithani, A. (2001): Metamorphism and exhumation of the northwest Himalaya constrained by U$\mathrm{Th}-\mathrm{Pb}$ analyses of detrital monazite grains from early foreland basin sediments. J. Geol. Soc. London 158, 625-635.

Whitehouse, M.J., Claesson, S., Sunde, T. \& Vestin, J. (1997): Ion microprobe U-Pb zircon geochronology and correlation of Archean gneisses from the Lewisian Complex of Gruinard Bay, northwestern Scotland. Geochim. Cosmochim. Acta 61, 4429-4438.

WiLliaMS, I.S. (1998): U-Th-Pb geochronology by ion-microprobe. In Applications of Microanalytical Techniques to Understanding Mineralizing Processes (M.A. McKibben, W.C. Shanks III \& W.I. Ridley, eds.). Rev. Econ. Geol. 7, 1-35.

WiLton, D.H.C. (1996): Metallogeny of the Central Mineral Belt and adjacent Archean basement, Labrador. Nfld. Dep. of Mines and Energy, Mineral Resource Rep. 8.

Received February 25, 2002, revised manuscript accepted April 10, 2003. 